\title{
KUALITAS SUMBERDAYA MANUSIA DALAM PERSPEKTIF EKONOMI ISLAM DI NUSA TENGGARA BARAT
}

\author{
Hj. Titiek Herwanti \\ herwantitiek@yahoo.com \\ Muhammad Irwan \\ Fakultas Ekonomi Universitas Mataram
}

\begin{abstract}
Government of West Nusa Tenggara was developed program called 3A (ADONO, ABSANO and AKINO) to fulfilled the needs of qualified human resources. That needs leads this reseach to determine the quality of human resources in NTB with further Islamic economic perspective analysis. This research using descriptive method, sources and types of data was secondary data from the years 2008 to 2012. Growth in every aspect was analized use end to end method. Economic growth was not qualified, because it is still supported by the capital-intensive sector (non-tradable). NTB Human Development Index was reached 66.88 and are on middle class welfare, but the position of NTB still ranks 32 out of 33 provinces. The qualified human resources based on Islamic economy perspective was someone with science, doing willingly with clean soul and protect their generation. Islamic economy require mankind to work to earn money for fullfilling the needs of themselves and their families. There is a rights of others that should be distributed based on obligatory and sunnah. Improving their human resources quality, NTB had implement elements based on Islamic economic perspective, however, the results have not reached the ideal condition, because there are behaviors that deviate from that goal.
\end{abstract}

Keywords: Qualified human resources, regional gross domestic product, capital-intensive, Islamic economics

\begin{abstract}
ABSTRAK
Pemerintah Nusa Tenggara Barat mengembangkan program 3A (ADONO, ABSANO dan AKINO) untuk mewujudkan SDM yang berkualitas. Pentingnya mewujudkan hal ini menjadikan penilaian kualitas SDM di NTB menjadi tujuan dalam penelitian ini dan akan dilanjutkan dengan analisis perspektif ekonomi Islam. Penelitian ini menggunakan metode deskriptif, sumber dan jenis data adalah data sekunder dari tahun 2008 - 2012. Tingkat Pertumbuhan dikaji menggunakan metode rata-rata End to End. Pertumbuhan Ekonomi tergolong belum berkualitas karena masih ditopang oleh sektor padat modal (non-tradeable). Indeks Pembangunan Manusia NTB telah mencapai 66,88 dan berada pada golongan kesejahteraan menengah, tetapi posisi NTB masih berada di urutan 32 dari 33 propinsi. SDM yang berkualitas dalam ekonomi Islam adalah yang memiliki ilmu pengetahuan, harus melakukan pekerjan dengan kondisi jiwa yang bersih dan menyelamatkan generasi pewaris keturunan. Ekonomi Islam mewajibkan umat manusia untuk bekerja agar penghasilannya dimanfaatkan untuk memenuhi kebutuhan diri dan keluarganya. Sebagiannya ada hak orang lain yang didistribusikan melalui distribusi harta baik yang wajib maupun sunnah. Kualitas SDM di Nusa Tenggara Barat telah menerapkan unsur-unsur yang berada di dalam perspektif ekonomi Islam, namun hasil yang diperoleh belum mencapai kondisi ideal, karena masih terdapat perilaku-perilaku yang menyimpang dari tujuan tersebut.
\end{abstract}

Kata Kunci : SDM Berkualitas, PDRB berkualitas, Padat modal, ekonomi Islam.

\section{PENDAHULUAN}

Sumber Daya Manusia (SDM) yang berkualitas merupakan modal dasar pembangunan suatu bangsa, agar Sumber daya alam (SDA) yang melimpah dapat dimanfaat kan. Untuk menghadapi tantangan tersebut, dibutuhkan SDM yang mempunyai daya tembus dan daya tangkal yang kuat karena 
kemampuan ilmu pengetahuan yang andal, keimanan dan ketakwaan yang kokoh, etos kerja, daya juang yang tinggi, suatu tanggung jawab kemasyarakatan dan kebangsaan yang tinggi pula (Mulyadi, 2012). SDM berkualitas memiliki produktivitas tinggi yang mampu memajukan pembangunan perekonomian bangsanya, karena perbedaan mendasar perekonomian antara negaranegara maju dengan negara-negara berkembang adalah meningkatnya produktivitas sumberdaya manusia di negara maju dibanding negara-negara berkembang (AlHaritsi, 2006).

Bangsa Indonesia menyadari bahwa SDM yang berkualitas merupakan impian yang terus diwujudkan mengingat hingga saat sekarang kondisi SDM Indonesia masih dikategorikan relatif rendah dari beberapa indikator diantaranya tingkat pendidikan, kesehatan (harapan hidup) dan tingkat pendapatan (ekonomi) yang diperoleh penduduk Indonesia. Berdasarkan Indek Pembangunan Manusia (IPM), Indonesia berada pada urutan 115 dari 174 negara di dunia pada tahun 2009 dan berada pada urutan 124 dari 187 negara pada tahun 2011 (Fauzi, 2012). Menurut Stamboel (2012) perekonomian nasional akan dapat dibangun bila diisi oleh SDM yang berkualitas dilihat dari kualitas pengetahuan, keterampilan dan pendidikannya. Hal ini juga berkaitan dengan kondisi kesehatan dan harapan hidup, karena kesehatan dan harapan hidup yang lebih baik menunjang produktivitas dalam aktivitas perekonomian. Oleh karenanya, berbagai ikhtiar dilakukan oleh pemerintah Indonesia untuk meningkatkan kualitas SDM agar dapat mensejajarkan diri dengan bangsa-bangsa lainnya di dunia.

Pemerintah Provinsi Nusa Tenggara Barat, juga terus berupaya untuk mewujudkan penduduk NTB menjadi SDM berkualitas. Sejak tahun 2009 pemerintah NTB melalui Rencana Pembangunan Jangka Menengah (RPJMD) 2009 - 2013, mencanangkan program peningkatan kualitas SDM melalui gerakan 3-A mencakup bidang kesehatan yang disebut AKINO (Angka Kematian Ibu menuju Nol), di bidang pendidikan yang disebut dengan ABSANO (Angka Buta Aksara menuju Nol) dan ADONO (Angka Drop-Out menuju Nol). Sedangkan di bidang Ekonomi untuk meningkatkan pendapatan masyarakat antara lain Pencanangan "Bumi Sejuta Sapi" dan Menciptakan 100 ribu wirausaha baru (Bappeda NTB, 2009). Proses pembangunan SDM yang dilakukan oleh pemerintah secara perlahan mencapai hasil menggembirakan, namun capaian tersebut belum mengangkat posisi Nusa Tenggara Barat pada Indeks Pembangunan Manusia (IPM) nasional yang masih pada posisi 32 dari 33 propinsi di Indonesia. Ikhtiar terus dilakukan, karena SDM yang berkualitas akan mampu mengantarkan daerah ini bersaing dan sejajar dengan daerah lain. SDM yang berkualitaslah yang mampu mengangkat harkat dan martabatnya sebagai makhluk ciptaan Tuhan yang terhormat, istimewa melebihi makhluk hidup lainnya.

SDM yang berkualitas dalam ekonomi Islam yang berlandaskan pada Al-Qur'an, Al-Hadist maupun Ijma telah lama dikumandangkan, ditandai dengan banyaknya firman Allah yang berkaitan dengan manusia di antaranya manusia yang beriman dan bertakwa sebagaimana yang dijadikan kriteria SDM yang berkualitas di atas. Salah satu firman Allah yang berkaitan dengan manusia beriman terdapat pada $S$. Al-Mujadilah ayat 11 yang artinya "Berdirilah kamu", maka berdirilah, niscaya Allah akan meninggikan orang-orang yang beriman di antaramu dan orang-orang yang diberi ilmu pengetahuan beberapa derajat. Ayat ini memberikan dua ciri sekaligus manusia yang berkualitas yaitu 1) beriman dan 2) berilmu pengetahuan, hasilnya akan mendapat derajat yang lebih tinggi. Merujuk pada ayat ini, untuk membangun perekonomian suatu bangsa dituntut manusia yang berilmu pengetahuan didasarkan pada keyakinannya (iman) dengan mengikuti petunjuk dari Allah SWT penciptanya maupun Rasulullah SAW. Bila suatu bangsa memiliki SDM yang berkualitas yang mampu meng- 
olah seluruh potensi SDA yang dimiliki, maka dipastikan perekonomian bangsa tersebut akan berada pada derajat yang lebih tinggi dibandingkan dengan negara atau bangsa yang tidak memiliki SDM berkualitas meskipun memiliki SDA yang melimpah.

SDA yang diciptakan Allah SWT jauh sebelum manusia diciptakan diberikan kebebasan terbatas kepada manusia untuk memanfaatkannya sesuai dengan kemampuan akal yang terdapat dalam diri manusia tersebut. Akal dipergunakan untuk merenungkan dan memikirkan bagaimana cara memanfaatkan potensi SDA yang melimpah ini agar berguna baginya dan syaratnya adalah manusia harus memiliki ilmu. Hal ini didasarkan pada salah satu hadist Rasulullah SAW yang artinya Menuntut ilmu adalah kewajiban atas setiap orang Islam laki-laki maupun perempuan (HR. Ibnu Majah). Berkaitan dengan hal tersebut manusia wajib menuntut ilmu sampai pada jenjang setinggi-tingginya tanpa batas selama masih menjalankan proses kehidupannya di dunia.

Konsekuensi dari SDM yang berkualitas dan memiliki ilmu pengetahuan adalah manusia diperintahkan untuk bekerja, mengolah lebih lanjut seluruh isi bumi guna memenuhi kebutuhannya. Hal ini dimaksud kan untuk menghindari manusia dari sifat malas, pasrah dan tidak beraktivitas (menganggur) yang berdampak timbulnya permasalahan sosial lainnya. Bekerja dalam ekonomi Islam merupakan kewajiban dan bernilai ibadah. Banyak firman Allah yang memerintahkan manusia untuk bekerja di antaranya dalam S. Al-Jumuah ayat 10 yang artinya : Apabila telah ditunaikan shalat, maka bertebaranlah kamu di muka bumi; dan carilah karunia Allah dan ingatlah Allah banyak-banyak supaya kamu beruntung. Dipertegas lagi oleh Hadist Rasulullah SAW yang artinya Orang yang menderita karena membiayai keluarganya, tak ubahnya seperti berjuang di jalan Allah (HR. Ali bin Abi Thalib). Perintah bekerja di atas, mendapatkan penekanan juga dari pemikirpemikir ekonomi konvensional di antaranya Cascio, (2003) yang menyatakan bahwa pekerjaan adalah hal yang amat penting bagi individu, karena pekerjaan menentukan standar kehidupan, tempat tinggal, status bahkan harga diri, sedangkan bagi organi sasi pekerjaan penting artinya karena merupakan kendaraan melalui mana tujuan organisasi dapat dicapai. Berdasarkan dari uraian di atas, maka SDA yang tersedia dapat dimanfaatkan jika diolah lebih lanjut oleh manusia yang memiliki pekerjaan sekaligus memiliki ilmu pengetahuan. Oleh karenanya, keberadaan SDM yang berkualitas dalam Ekonomi Islam menjadi syarat utama dalam menata perekonomian suatu bangsa yaitu beriman, berilmu dan berakhlaq mulia dalam mengolah SDA yang tersedia sehingga mampu mengangkat derajat penduduk suatu bangsa yang lebih tinggi.

Propinsi NTB dianugerahi oleh Allah SWT dengan potensi besar baik dilihat dari jumlah penduduk (SDM), SDA maupun keragaman budaya dan adat istiadat. Dalam konteks keagamaan, daerah ini dikenal dengan sebutan daerah "Seribu Masjid" yang mencirikan fanatisme terhadap pelaksanaan ajaran agama relatif tinggi terutama agama Islam yang dianut mayoritas penduduknya. Dilihat dari letak geografisnya, daerah ini persis berada di lintasan tujuan wisata utama dunia: Bali-Komodo dan Tanah Toraja yang sering disebut dengan "segitiga emas pariwisata Indonesia". Berdasarkan potensi yang melimpah ini, setidaknya akan memberikan nilai tambah bagi pemerintah NTB yang dijadikan modal dasar pembangunan jangka panjang 2005 2025 dengan visi "Terwujudnya Masyarakat Nusa Tenggara Barat Yang Beriman, Maju dan Sejahtera (Bappeda NTB, 2009). Visi ini akan dapat digapai dan diwujudkan bila dalam tata kelola pemerintahan, aktivitas ekonomi maupun kegiatan lainnya dilakoni oleh SDM yang berkualitas, disertai dengan kualitas iman yang dicerminkan oleh akhlaknya.

Berdasarkan uraian tersebut, permasalahan difokuskan pada bagaimana Kualitas SDM di Nusa Tenggara Barat dilihat dari indikator pendidikan, kesehatan maupun kondisi ekonomi maupun Perspektif Eko- 
nomi Islam. Tulisan ini bertujuan untuk menganalisis dan mengetahui kondisi SDM NTB dikaitkan dengan karakteristik SDM yang berkualitas dalam pandangan Ekonomi Islam. Tulisan ini diharapkan akan menjadi tambahan informasi berbagai pihak yang memiliki minat dalam kajian SDM dan juga sebagai referensi bagi peminat Ekonomi Islam dalam mengembangkan SDM.

\section{TINJAUAN TEORETIS \\ Penelitian Sebelumnya}

Indeks Pembangunan Manusia (IPM) atau Human Development Index (HDI) merupakan indikator yang diajukan oleh UNDP untuk melihat unsur pembangunan manusia. Bagi Indonesia, perhatian pada variabel indeks pembangunan manusia sangat penting karena (1) Pembangunan pada hakekatnya merupakan pembangunan manusia itu sendiri, sehingga aspek ini perlu mendapatkan prioritas anggaran; (2) Pembangunan manusia pada saat ini masih sangat tertinggal di banding banyak negara lain di dunia (Hamid, 2002). Hasil penelitian nya terhadap komponen IPM di Yogjakarta menunjukkan bahwa, pola pengeluaran rumah tangga masyarakat di Yogyakarta untuk konsumsi pendidikan dan konsumsi bidang kesehatan relatif tinggi. Dilihat secara proporsional dari pendapatannya, bagian pendapatan yang dikeluarkan untuk konsumsi pendidikan dan kesehatan paling tinggi dibanding daerah lain. Wiyono (2003) mengatakan bahwa untuk meningkatkan kualitas SDM di era globalisasi pemerintah harus tetap berkomitmen untuk meningkatkan anggaran pendidikan, menaikkan dana kesehatan dan mendorong terjadinya proses pemberdayaan masyarakat di semua bidang kehidupan. Pada kontek lain, Setiawan dan Hakim (2013) dalam tulisannya tentang Indeks Pembangunan Manusia dengan memodelkan perilaku Indeks Pembangunan Manusia ke dalam variabel-variabel independen yang dipertimbangkan adalah Produk Domestik Bruto (PDB), Pajak Pendapatan (PPN), variabel dummy desentralisasi pemerintahan, variabel dummy krisis tahun 1997, dan variabel dummy krisis tahun 2008. Dengan menggunakan Error Correction Model (ECM), menemukan bahwa PDB dan PPN berpengaruh terhadap IPM dalam jangka panjang maupun jangka pendek. Estimasi model ECM menemukan bahwa krisis ekonomi tahun 2008 berpengaruh terhadap IPM, sementara krisis tahun 1997 dan desentralisasi pemerintahan tidak berpengaruh terhadap IPM.

Menurut Notoatmodjo (2009), SDM dapat dilihat dari dua aspek yaitu kuantitas dan kualitas. Kuantitas menyangkut jumlah SDM atau penduduknya yang kurang penting kontribusinya dalam pembangunan, dibandingkan dengan aspek kualitas SDM. Kualitas SDM menyangkut kemampuan baik kemampuan fisik maupun non fisik (kecerdasan dan mental). Lebih lanjut dikata kan bahwa yang menentukan kualitas SDM suatu bangsa adalah a). Pendidikan, yang terdiri dari Angka Melek huruf atau buta huruf, Angka Partisipasi Sekolah, Angka rata-rata sekolah; b). Kesehatan terdiri dari Angka Kematian Bayi, Angka Kematian Balita, Angka Kematian Ibu, Angka Kematian Kasar dan Usia Harapan Hidup; c) Ekonomi yang terdiri dari Kesejahteraan atau Kemiskinan penduduk (SDM). d). Indek Pembangunan Manusia. Menurut Santoso (2012) salah satu faktor yang mempengaruhi Kualitas SDM adalah Modal Manusia (human capital) yang terdiri dari Karakter individu misalnya tingkat kecerdasan, kecakapan dan ambisi; tingkat kesehatan dan tingkat keterampilan. Sementara Mulyadi (2012) mengatakan bahwa salah satu kebijaksanaan dalam peningkatan SDM adalah peningkatan kualitas hidup yang dilakukan dengan a) pembangunan pendidikan; b) pembangunan kesehatan; c) peningkatan kualitas penduduk miskin melalui keterampilan praktis, mendorong semangat keswadayaan dan d) menekan laju pertumbuhan penduduk.

SDM atau disebut sebagai Sumber Daya Insani (SDI) meskipun kata Insan dan Manusia memiliki arti yang sama, namun dalam Islam dikenal adanya konsep insan 
kamil atau manusia seutuhnya (a whole man concept) oleh Iqbal seorang filosof Muslim berpendapat bahwa insan kamil adalah mukmin yang dalam dirinya terdapat kekuatan wawasan, perbuatan dan kebijaksanaan. Sifat luhur ini dalam wujudnya yang tertinggi tergambar dalam akhlak Nabi (Jusmaliani, 2011), sedangkan Danim (2004) lebih suka menyebut Sumber Daya Insani (SDI) dari SDM karena kata "Insan" lebih bermakna kemanusiaan ketimbang makna manusia umumnya, apalagi manusia sebatas sosok fisik yang berbeda bentuk dibandingkan dengan bentuk makhluk Tuhan yang lainnya. Lebih lanjut dikatakan manusia yang berkualitas secara kognitif, afektif, prikomotorik, emosi dan spirit insaniah adalah modal utama ketika peradaban makin memodern. SDM atau SDI masa depan yang dikehendaki adalah yang bermutu, bukan yang kuat dalam makna fisik, apalagi hanya sebatas menonjolkan keagungan sejarah dan membusungkan dada karena SDA (SDA) yang melimpah yang akan hangus ditelan oleh perilaku yang rakus yang seakan-akan tidak ada batasnya.

SDM (Insani) yang berkualitas dalam Ekonomi Islam merupakan suatu keniscayaan, karena sejak awal manusia diciptakan dan diturunkan di bumi adalah, untuk memakmurkan bumi dan isinya agar manusia itu mencapai kemakmurannya. Untuk hal itu, ketika Nabi Muhammad menerima wahyu pertama dari Allah SWT diperintahkan untuk membaca dengan nama Tuhan. Ini bermakna bahwa alam yang luas ini harus dikelola oleh manusia yang berkualitas baik dari aspek jasmani maupun rohani. Syarat pertama adalah harus berilmu (berpendidikan). Selain mengangkat derajat orang yang berilmu, Rasulullah SAW melalui hadisnya menyatakan bahwa Tuntutlah ilmu dari buaian hingga liang lahat. Berkaitan dengan pengembangan SDM (insani) yang berkualitas, Umar Ibn Khattab (Al-Haritsi, 2006) menekankan pada dua sifat yang mendasar di dalamnya yaitu kuat dan amanah, dimana dua sifat ini merupakan pilar utama dari kepemimpinan sebagaimana firman
Allah dalam Qs. Al-Qashash, 26 yang artinya "Sesungguhnya orang yang paling baik yang kamu ambil untuk bekerja (pada kita) ialah orang yang kuat lagi dapat dipercaya. Dua sifat ini, oleh Ibnu Taimiyah dijelaskan bahwa kekuatan dalam setiap kepemimpinan adalah sesuai porsinya, artinya memiliki keberanian hati, pengalaman dalam perang, tipu daya di dalamnya, karena perang adalah tipu daya dan menguasai bentuk-bentuk peperangan, sedangkan kuat dalam bidang penetapan hukum, di antara manusia adalah berarti berlaku adil, berdasarkan Al-Qur'an dan AsSunnah, dan mampu melaksanakan hukum. Sementara amanah adalah berarti takut kepada Allah dengan tidak menjual ayatayat-Nya dengan kehidupan dunia, dan meninggalkan rasa takut kepada manusia. Aspek lainnya adalah Pelatihan dan Meraih keterampilan (pendidikan); Makanan, Kesehatan dan Kepedulian Sosial. Manusia yang kuat dan unggul sebagai ciri SDM yang berkualitas juga terdapat dalam Hadist Rasulullah SAW yang diriwayatkan oleh Muslim yang pada intinya mengandung unsur iman yang kuat, menggali kemampuan (ability) dan memperbanyak perbuatan yang bermanfaat (Diana, 2008).

Aedy (2011) mengatakan bahwa SDM berkualitas yang menjadi modal pembangunan perspektif Islam baik secara fisik maupun secara mental (spritual) adalah 1) SDM yang berkarya dengan akhlak mulia; 2) SDM yang cerdas, kerja keras dan Inovatif; 3) SDM yang bersahabat dengan alam; 4) SDM yang beriman dan bertakwa. Untuk membangun SDM (insani) yang unggul diperlukan upaya-upaya sadar dengan meningkatkan 6 K (Aziz dan Ulfah, 2010) yaitu (1) Kekuatan iman (quwwatul iman); (2) Kekuatan Ilmu (quwwatul ilmu), (3) Kekuatan moral (quwwatul akhlak), (4) Kekuatan semangat (quwwatul jihad); (5) Kekuatan ekonomi (quwwatul iqtishad), (6) Kekuatan kesetiakawanan (quwwatul tamsuk al-Ijtima'iy). Berdasarkan karakteristik dari SDM yang berkualitas adalah SDM yang memiliki ilmu pengetahuan (pendidikan), memiliki kondisi kesehatan yang kuat dan unggul, memiliki kemampu- 
an ekonomi yang mapan, serta memiliki karakteristik spritual yang beriman, bertakwa dan amanah. Oleh karenanya SDM yang berkualitas tidak hanya terfokus pada pemenuhan unsur jasmaniah belaka namun secara bersamaan harus diwujudkan pula pemenuhan kebutuhan rohaniahnya.

\section{METODE PENELITIAN}

Penelitian ini merupakan penelitian deskriptif yang mendeskripsikan kondisi SDM di NTB pada tahun 2008-2012. Data yang dipergunakan semuanya data sekunder baik yang bersumber dari Instansi terkait maupun yang terdapat dalam literaturliteratur yang memiliki hubungan dengan analisis ini. Jenis datanya adalah data runtun waktu mulai tahun 2008-2012. yang dianalisis dengan menggunakan tabel dan grafik, selanjutnya dijelaskan secara kualitatif khususnya yang berkaitan dengan angkaangka. Tingkat pertumbuhan pada masingmasing aspek kajian menggunakan Metode rata-rata End to End. Kualitas SDM atau Sumber Daya Insani (SDI) yang dikaji adalah: Tingkat pendidikan, Kesehatan, Ekonomi yang terdiri dari besarnya pendapatan perkapita atau paritas daya beli, Jumlah penduduk miskin dan Jumlah penduduk yang menganggur, Pertumbuhan Ekonomi dan Indeks Pembangunan Manusia (IPM). Analisis kualitatif difokuskan pada uraian tentang ciri-ciri manusia yang berkualitas dalam kontek ekonomi Islam sebagai landasan utama dalam merencanakan untuk mengembangkan sekaligus mewujudkan SDM (insani) yang berkualitas sebagai modal pembangunan bangsa Indonesia.

\section{ANALISIS DAN PEMBAHASAN Pendidikan}

Kondisi pendidikan di NTB mengalami perubahan dan kemajuan seiring dengan ikhtiar yang dilakukan oleh pemerintah daerah untuk meningkatkan kualitas SDM (Tabel 1). Pada Tabel 1 dapat dilihat bahwa kualitas pendidikan masyarakat NTB mengalami kemajuan ditandai oleh semakin menurunnya jumlah penduduk yang tergolong sebagai Buta Huruf yang semula $80,13 \%$ pada tahun $2008 / 2009$ mencapi 83,68 $\%$ pada tahun 2012/2013 atau tersisa $16,32 \%$ dari total penduduk yang tergolong Buta Huruf yang direncanakan akan dituntaskan pada tahun 2013. Penduduk yang pernah menempuh pendidikan tetapi putus ditengah jalan (Drop Out = DO) pada berbagai jenjang pendidikan mengalami penurunan yang cukup banyak terkecuali pada jenjang Sekolah Menengah Atas (SMA) sederajat yang penurunannya relatif kecil. Dilihat dari rata-rata lama sekolah masyarakat NTB pada tahun 2012/2013 telah mencapai 7,19 tahun atau pada saat tersebut berada pada kelas 1 sekolah Menengah Pertama (SMP) sederajat. Meskipun secara kuantitas mengalami peningkatan, namun dikaitkan dengan pro gram pemerintah yang mengikhtiarkan penduduk untuk wajib belajar pada usia 9 tahun ternyata belum terpenuhi, sehingga pemerintah NTB masih membutuhkan kerja keras untuk mewujudkannya pada masa mendatang.

Tabel 1

Pencapaian Program Pendidikan di Nusa Tenggara Barat Tahun 2008 - 2013 Dari Beberapa Indikator

\begin{tabular}{lrrrrr}
\hline \hline \multirow{2}{*}{ Indikator } & \multicolumn{5}{c}{ Tahun } \\
\cline { 2 - 6 } & $\mathbf{2 0 0 8 / 2 0 0 9}$ & $\mathbf{2 0 0 9 / 2 0 1 0}$ & $\mathbf{2 0 1 0 / 2 0 1 1}$ & $\mathbf{2 0 1 1 / 2 0 1 2}$ & $\mathbf{2 0 1 2 / 2 0 1 3}$ \\
\hline $\begin{array}{l}\text { Angka Melek } \\
\text { Huruf (\%) }\end{array}$ & 80,13 & 80,18 & 81,05 & 83,24 & 83,68 \\
$\begin{array}{l}\text { Rata-Rata Lama } \\
\text { Sekolah (tahun) }\end{array}$ & 6.70 & 6.73 & 6.77 & 6,97 & 7,19 \\
\hline
\end{tabular}

Sumber : BPS dan Bappeda NTB, 2012 diolah 
Ikhtiar tersebut di samping menuntaskan masyarakat dari Melek Huruf juga memberikan kesempatan yang seluas-luasnya kepada masyarakat untuk melaksanakan pendidikan terutama pada pendidikan formal, sehingga SDM NTB akan menjadi SDM yang memiliki kemampuan dan keahlian untuk memasuki dunia kerja, tidak hanya terfokus untuk menjadi tenaga kerja luar negeri dengan berbekal pendidikan yang sangat rendah. Berdasarkan tabel di atas, pemerintah Nusa Tenggara Barat dari tahun ke tahun secara konsisten berusaha membebaskan penduduknya dari buta huruf dan putus sekolah. Hal ini disadari karena pendidikan merupakan salah satu faktor penting yang menentukan kualitas SDM bahkan merupakan kebutuhan pokok (dasar), karena dengan berpendidikan manusia Indonesia dapat mengangkat harkat dan martabatnya sebagai manusia. Pendidikan merupakan suatu proses penyiapan subjek didik untuk menuju masa depan yang bertanggung jawab (Danim, 2004). Begitu pentingnya pendidikan untuk masa depan umat manusia, maka dalam kontek ekonomi pendidikan merupakan suatu investasi yang dikenal dengan (human investment). Lebih lanjut Danim mengatakan bahwa Investasi dibidang pendidikan termasuk pelatihan dan pengembangan, sehingga muncul tiga serangkai kemampuan dan siklus hidup manusia yaitu kemampuan ekonomi, kemampuan berinvestasi dan kemampuan berpendidikan (Gambar 1).

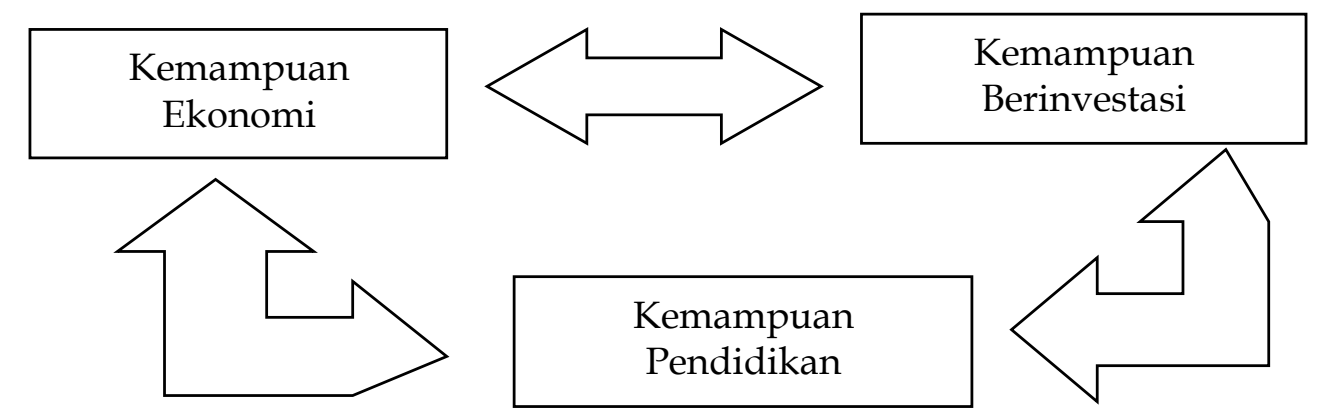

\section{Gambar 1}

Sumber: Danim (2014)

Tiga Serangkai Kemampuan dalam Siklus Hidup Manusia rikut:

Keterkaitannya dijelaskan sebagai be-

a. SDM yang berpendidikan secara bermutu mengambil peran penting dalam merangsang pertumbuhan ekonomi.

b. Proses kerja pendidikan dan investasi pendidikan secara ekonomi harus dikaitkan dengan peramalan (forecasting) kebutuhan SDM, antara lain dengan melembagakan pendidikan kedinasan yang luarannya dimanfaatkan secara instan.

c. Pembiayaan pendidikan dan efektivitas penggunaannya harus diukur dengan nilai ekonomi yang diperoleh atas uang yang diinvestasikan untuk membiayai pendidikan itu. d. Investasi pendidikan dan penelitianpenelitian mengenai ekonomi harus dilihat dalam kaitannya dengan kemampuan mendapatkan keuntungan dan kesejah teraan.

Peningkatan kualitas SDM merupakan keniscayaan yang harus dilakukan oleh pemerintah pusat maupun pemerintah daerah (NTB), karena merupakan hak asasi manusia sekaligus kewajiban agama utama agama Islam. Pendidikan dalam perspektif Islam adalah suatu proses penyampaian informasi (berkomunikasi) yang kemudian diserap oleh masing-masing pribadi (internalisiasi), sehingga menjiwai cara berpikir, bersikap dan bertindak (individuasi) baik untuk 
dirinya sendiri maupun hubungannya dengan Allah (ibadah) dan hubungannya dengan manusia lain atau masyarakat (sosialisasi) serta makhluk lain dalam alam semesta maupun lingkungan (muamalah ma'al makhluk atau kultural civilisasi) dalam kedudukannya sebagai a) hamba Allah; b) Khalifah Allah di bumi (Kaelany, 2005; 240). Kebutuhan pendidikan dalam ekonomi Islam termasuk dalam salah satu maqashid syariah yang harus dijaga yaitu menjaga Akal atau ilmu. Tidak dapat dinafikan bahwa ketika Muhammad SAW mau diangkat menjadi seorang Rasul dan Nabi, syarat pertama yang diwajibkan kepadanya adalah membaca seluruh alam jagad raya ini dengan nama Tuhan yang menciptakan sebagaimana firman Allah dalam surat Al-Alaq ayat 1 - 5 yang artinya (1) Bacalah dengan Nama Tuhanmu yang menciptakan; (2) Dia telah menciptakan manusia dari segumpal darah; (3) Bacalah, dan Tuhanmulah yang Maha Pemurah; (4) Yang mengajar (manusia) dengan perantaraan kalam; (5) Dia mengjar kepada manusia apa yang tidak diketahuinya. Dengan membaca isi alam berdasarkan akal, manusia akan memperoleh pengetahuan yang selanjutnya akan mengembangkan segala fasilitas (sumberdaya) yang tersedia untuk memenuhi kewajibannya. Penekanan ekonomi Islam dalam menjaga akal ini dimaksudkan agar manusia mampu membaca sekaligus mengolah sumberdaya alam yang masih bersifat asli untuk diproses lebih lanjut agar dimanfaatkan guna menjadi barang-barang bernilai ekonomi yang bermuara pada terpenuhinya kebutuhan hidup baik pokok (daruriyah) maupun sekunder dan pelengkap (tahsiniyah dan hajiyat). Dengan demikian, kewajiban menempuh pendidikan merupakan suatu keniscayaan dan akan mengangkat harkat dan martabatnya sebagai manusia. Penekanan ekonomi Islam menjaga akal juga terungkap dari tugas ekonomi Islam salah satunya adalah memerangi kebodohan yaitu orang yang tidak berakal, yang tidak memfungsikan akalnya dengan baik, yaitu orang yang menyembah, ber- bakti, takut bekerja serta beribadah selain Allah ta'ala (Zadjuli, 2007).

Akal merupakan sarana yang menjembatani manusia untuk melakukan sesuatu perbuatan baik atau buruk. Dalam upaya pemenuhan kebutuhan manusia baik ekonomi maupun non ekonomi termasuk kebutuhan pendidikan, manusia harus menggunakan akal mengikuti kaidah-kaidah yang sesuai dengan syariat. Salah satu fungsi akal adalah untuk memikirkan berbagai ciptaan Allah di muka bumi untuk dikelola agar bermanfaat bagi manusia. Hasil pemikiran dan perenungan akal melahirkan pengetahu an atau melahirkan suatu ilmu. Dengan ilmu manusia dapat memenuhi semua keinginan dan kebutuhannya baik di dunia maupun akhirat, selama berada dalam koridor yang diperbolehkan. Sebab dengan berilmu manusia akan menggapai hal tersebut sebagai mana sebuah ungkapan "barang siapa yang ingin sukses dalam kehidupan dunianya, hendaklah (dicapai) dengan ilmu, barang siapa yang ingin selamat di akhirat nanti hendaklah dengan ilmu dan barang siapa yang ingin sukses dan menghadapi kedua-duanya (dunia dan akhirat) maka hendaklah pula dicapai dengan ilmu". Kebutuhan manusia terhadap ilmu pengetahuan dengan menggunakan akal sebagai sarana untuk berpikir, merupakan konsekuensi sebagai salah satu tugas pokoknya sebagai khalifah yang menata serta memanfaatkan bumi dan isinya. Manusia yang berilmu pengetahuan dapat memanfaatkan dan memelihara seluruh alam dan isinya untuk mencapai kesejahteraan. Alam beserta isinya diperuntukkan bagi manusia, sehingga dengan ilmu pengetahuan yang dimilikinya, manusia dapat melakukan perubahan atau merekayasa seluruh isi alam yang masih dalam keadaan asli diolah lebih lanjut sehingga menjadi barang dan jasa yang bernilai ekonomi, yang semuanya untuk dimanfaatkan lebih lanjut untuk keberlangsungan hidupnya di dunia guna menuju kehidupan akhirat yang kekal. Dengan kemampuan ilmu pengetahuan yang dimilikinya sebagai produk dari akal, maka tidak heran manusia dikatakan sebagai 
"pencipta kedua" setelah Tuhan. Karena manusia dianugerahi rasio oleh Tuhan itu mampu menciptakan kreasi canggih berupa sains dan tekhnologi, sementara malaikat diperintah sujud kepada-Nya karena tidak mampu bersaing secara intelektual. Kelebihan intelektual inilah yang menjadikan manusia lebih unggul dari makhluk lainnya, tetapi iapun bisa menjadi dekaden, bahkan lebih rendah nilainya dari binatang jika melakukan tindakan deskruptif, melepaskan imannya sebagaimana firman Allah dalan SAt-Tin 5-6 dan S. Al-A'raf 179 (Zainuddin, 2006).

Pengembangan ilmu pengetahuan bagi seorang muslim merupakan suatu kewajiban, dan tidak akan berhenti selama manusia itu masih hidup. Pengembangan ilmu pengetahuan harus mengacu pada landasan utama atau pedoman hidup Al-Qur'an dan Al-Hadist karena ilmu pengetahuan bersumber dari 2 pedoman utama tersebut. Manusia dengan kemampuan akal yang dimiliki, melakukan analisis dan kajian yang lebih mendalam dan berulang-ulang sehingga akan mampu menciptakan tekhnologi baru yang bermanfaat bagi keberlanjutan kehidupan manusia. Menurut Kaelany (2005) ilmu pengetahuan yang dihasilkan dari pengalaman merupakan kebenaran alami atau ketentuan-ketentuan yang berasal dari ilmu Allah yang disebut sunnatullah (ayat kauniyah). Sedangkan yang berasal dari informasi wahyu merupakan bukti kebenaran yang diturunkan Allah kepada para rasul-Nya dalam bentuk wahyu (disebut ayat tanziliah). Proses terciptanya ilmu pengetahu an dapat dilihat pada Gambar 2.

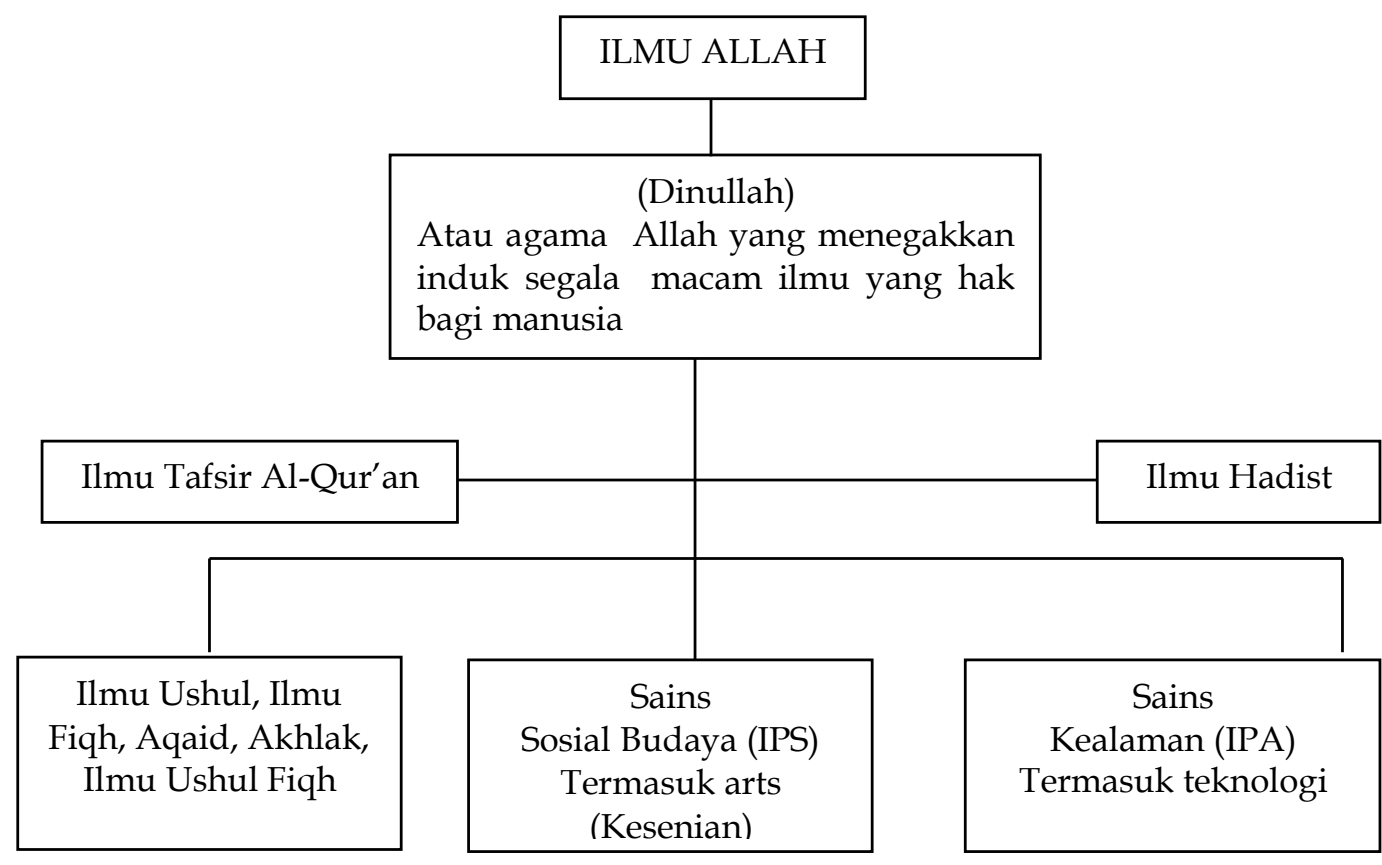

Gambar 2

Sumber : Kaelany (2005)

\section{Proses Terciptanya Ilmu Pengetahuan}

Pada Gambar 2 dapat dilihat bahwa ilmu pengetahuan bersumber dari Ilmu Allah yang diturunkan melalui agama yang memiliki pedoman Al-Qur'an dan AlHadist. Pedoman tersebut ditafsir dan dianalisis sehingga melahirkan berbagai cabang ilmu pengetahuan yang semuanya bermuara untuk pemenuhan kebutuhan hidup manusia. Oleh karenanya, ilmu pengetahuan harus dimiliki oleh setiap manusia dan wajib dituntut melalui suatu proses yaitu pendidikan. Dampak dari 
pendidikan ini adalah mampu merubah prilaku manusia, mampu menjaga kestabilan emosional, mampu melakukan interaksi sesama manusia serta mampu mengangkat harkat dan martabatnya. Karena pentingnya ilmu pengetahuan sebagai produk dari akal pikiran untuk kemaslahatan hidup manusia, maka ekonomi Islam menempatkan pada urutan ketiga dalam urutan pemeliharaan kebutuhan manusia setelah kebutuhan memelihara agama dan kebutuhan memelihara jiwa baru diikuti memelihara keturunan dan harta. Akal yang terpelihara dengan baik, manusia mendapatkan petunjuk menuju ma'rifat kepada Tuhan Penciptanya. Dengan akalnya, dia menyembah dan menaati-Nya, menetapkan kesempurnaan dan keagungan untuk-Nya, mensucikan-Nya dari segala kekurangan dan cacat, membenarkan para rasul dan para nabi, dan mempercayai mereka adalah perantara yang akan memindah kan kepada manusia yang diperintahkan Allah kepada mereka, membawa kabar gembira untuk mereka dengan janji dan membawa peringatan dan ancaman. Maka manusia mengoperasikan akal mereka, mempelajari yang halal dan haram, yang berbahaya dan bermanfaat, serta yang baik dan buruk (Jauhar, 2009). Ilmu pengetahuan harus diperoleh melalui pendidikan yang merupakan sebuah investasi bagi masyarakat yang memiliki karakteristik berikut (Djuwariyah, 2008) 1). Manusia berwatak, yaitu jujur dan memiliki social capital: dapat dipercaya, suka kerja keras, jujur dan inovatif. Dengan istilah lain, manusia yang beretika dengan taat menjalankan ajaran agama nya; 2). Cakap dan intiligen; harus dikembangkan sesuai dengan yang dimiliki masing-masing individu; 3). Enterpreneur, wiraswasta, bukan hanya di bidang ekonomi, tetapi seluruh aspek kehidupan, 4). Kompetitif, yang memiliki kualitas kompetitif dalam kehidupan dunia, terbuka untuk selalu menggapai nilai lebih dan meningkatkan kualitas produktifitas kerjanya.

Berdasarkan realitas capaian pendidi kan di NTB dilihat dari Angka Buta Huruf dan Rata-rata lama sekolah, untuk men- dorong masyarakat agar terus menikmati pendidikan formal telah dilakukan langkahlangkah strategis berkaitan dengan pengembangan mutu SDM di bidang pendidikan antara lain pemberian beasiswa kepada penduduk yang tergolong miskin pada jenjang SD- SMA, S-1, S-2, S-3, juga memberikan pembinaan kepada pelajar dan mahasiswa yang berprestasi di bidang akademik, olahraga dan pemuda (NTB Bersaing, Ikhtiar dan Fakta, 2009-2011). Demikian halnya dengan pendidikan non formal, terus diupayakan untuk mengurangi penduduk yang tergolong Buta Huruf. Kebijakan strategis ini sejalan dengan norma dalam ekonomi Islam melalui tercapainya maqashid syariah salah satunya menjaga agama dan menjaga Ilmu (akal).

\section{Kesehatan}

Kesehatan merupakan salah satu indikator kualitas SDM, karena dengan raga dan jiwa yang sehat SDM dapat melakukan aktivitasnya secara sempurna. Kondisi kesehatan yang baik bagi suatu daerah juga merupakan suatu indikasi keberhasilan daerah tersebut dalam membangun dan membentuk karakteristik masyarakat, sehingga dapat mengambil peranan dalam ikut membangun daerahnya. Pembangunan bidang kesehatan tidak saja terfokus pada aspek fisik melainkan juga pembangunan kesehatan jiwa, karena membangun kesehatan dengan memprioritaskan kesehatan fisik tidak akan bermakna tanpa dibarengi dengan pembangunan kesehatan jiwa. Menyadari akan pentingnya arti kesehatan dalam membangun manusia sekaligus membangun daerah, Propini NTB telah berusaha keras memperbaiki kondisi kesehatan masyarakat. Hal ini dilihat dari beberapa indikator seperti Usia Harapan Hidup (UHH), adalah perkiraan rata-rata tambahan umur seseorang yang diharapkan dapat terus hidup. Sehingga pada umumnya ketika membicarakan $\mathrm{AHH}$, yang dimaksud adalah rata-rata jumlah tahun yang akan dijalani oleh seseorang sejak orang tersebut lahir. Angka Kematian Bayi (AKB) adalah banyaknya kematian bayi 
usia dibawah satu tahun per 1000 kelahiran hidup pada satu tahun tertentu, dan Angka Kematian Ibu (AKI) adalah kematian perempuan ketika hamil atau dalam 42 hari setelah terminasi kehamilan (melahirkan/keguguran/aborsi) yang disebabkan oleh hal-hal terkait dengan kehamilan atau pemeliharaan nya.

Pada Tabel 2 terlihat bahwa Usia Harapan Hidup penduduk NTB diharapkan mengalami peningkatan dari tahun ke tahunnya meskipun lonjakannya tidak terlalu tinggi, yang semula hanya 61,5 tahun pada tahun 2008 menjadi 62,71 tahun pada tahun 2012. Peningkatan usia harapan hidup ini dapat diwujudkan bila ada usaha maksimal yang dilakukan baik secara internal dan eksternal. Usaha yang dilakukan penduduk secara internal seperti terjadinya peningkatan kesadaran tentang arti dan manfaat kesehatan dengan mengkonsumsi makanan yang bergizi, menjaga kebersihan dalam segala aspek serta melakukan pengobatan secara teratur ketika sedang jatuh sakit terutama pada fasilitas pemerintah maupun dokter-dokter praktek. Melakukan aktivitas yang dapat terhindar dari serangan penyakit yang mematikan (olahraga yang teratur), kondisi lingkungan sosial budaya serta adanya pembawaan yang berasal dari lingkungan keluar ga, sedangkan faktor ekternal berasal dari kebijakan-kebijakan yang dilakukan oleh pemerintah daerah Provinsi Nusa Tenggara Barat dalam menyediakan berbagai fasilitas kesehatan, akses yang mempermudah masyarakat untuk memenuhi kebutuhannya terutama berkaitan dengan pola konsumsi dan pengobatan serta fasilitas umum yang berdampak pada perbaikan kualitas hidup masyarakat. Semua usaha tersebut diharapkan akan mampu menjadikan manusia NTB memiliki harapan hidup yang lama meskipun sesungguhnya kehidupan tersebut di tentukan atas kehendak Allah SWT.

Tabel 2

Kondisi Kesehatan Penduduk Nusa Tenggara Barat Dilihat dari Beberapa Indikator

\begin{tabular}{lccccc}
\hline \multicolumn{1}{c}{ IndikatorKesehatan } & \multicolumn{5}{c}{ Tahun } \\
\cline { 2 - 6 } & $\mathbf{2 0 0 8}$ & $\mathbf{2 0 0 9}$ & $\mathbf{2 0 1 0}$ & $\mathbf{2 0 1 1}$ & $\mathbf{2 0 1 2}$ \\
\hline Usia Harapan Hidup (Tahun) & 61,50 & 61,80 & 62,11 & 62,41 & 62,71 \\
Angka Kematian Ibu Melahirkan (/100000 & 92 & 121 & 111 & 130 & 100 \\
KH) & & & & & \\
Angka Bayi Lahir Mati (Jiwa) & 577 & 545 & 608 & 646 & 763 \\
\hline
\end{tabular}

Sumber : Bappeda NTB, 2012, NTB Dalam Angka 2009 - 2013

Masa hidup di dunia yang relatif panjang merupakan dambaan bagi setiap orang, serta menunjukkan adanya keberhasilan usaha pemerintah yang serius berkaitan dengan pemenuhan kebutuhan dasar masyarakat dalam bidang ekonomi dan kesehatan. Namun pada sisi lain, lamanya manusia menjalani kehidupan di dunia berdampak pada bertambahnya penduduk yang tergolong usia tua (lansia) yang terkadang masalah ini menimbulkan gejolak sosial ekonomi. World Health Organization (WHO) menggolongkan lanjut usia menjadi 4 yaitu usia pertengahan (midle age) 45-49 tahun, lanjut usia (elderly) 60-74 tahun, lanjut usia tua (old) 75-79 tahun dan usia sangat tua (very old) di atas 90 tahun (Wattie, 2007). Dikaitkan dengan golongan ini, maka penduduk NTB dengan usia harapan hidup mencapai 62,71 tahun pada tahun 2012 termasuk pada golongan lanjut usia (elderly) dengan usia 60-74 tahun. Peningkatan usia harapan hidup hingga mencapai manusia lanjut usia, membawa konsekuensi pada aktivitas ekonomi terutama kemampuannya untuk bekerja guna menghasilkan pendapatan. Sering terlihat bahwa penduduk yang tergolong tua masih melakukan pekerjaan dengan berbagai faktor yang melatarbelakanginya. Jenis pekerjaan yang dilaku- 
kan hampir pada semua sektor baik berjenis kelamin laki-laki maupun perempuan. Pada sisi lain, pemerintah telah membatasi usia kerja seseorang untuk mengabdi pada bangsa dan negara pada usia 56-70 tahun, dan akan pensiun jika telah melewati batas usia tersebut, tetapi setelah memasuki usia pensiun, tidak sedikit di antaranya melakukan pekerjaan dengan tujuan memperoleh pendapatan guna memenuhi kebutuhan hidup diri dan tanggungannya, atau juga untuk mengisi waktu kosong dengan bekerja tidak menerima upah bahkan sebahagian besar mengisi aktivitas dengan menambah frekuensi ibadah sebagai bekal kehidupan di akhirat. Bekerja bagi penduduk usia lanjut berdampak pada produktivitas kerja yang dihasilkan, meskipun mereka tergolong sebagai tenaga "potensial produktif" bila mereka masih mampu melakukan pekerjaan setidaknya selama satu jam sehari dalam seminggu. Berkaitan dengan hal ini, lansia potensial produktif dibedakan menjadi dua yaitu (1). Lansia potensial produktif yang produktif, yaitu mereka yang bekerja dengan tujuan mencari nafkah atau membantu mencari nafkah atau keuntungan atau dengan tujuan lain meliputi: a) lansia pada pekerjaan dibayar (paid work) yaitu lansia yang mem- peroleh upah, gaji, komisi atau keuntungan; b) lansia pada pekerjaan tidak dibayar (unpaid worker), yaitu mereka yang bekerja pada usaha keluarga yang tidak memperoleh bayaran yang terkait langsung dengan pekerjaannya; (2). Lansia potensial produktif, tetapi tidak melakukan aktivitas produktif, yaitu mereka yang melakukan aktivitas rumah tangga, atau aktivitas sosial lainnnya (Yasa, 2002). Keterlibatan manusia lansia dalam aktivitas sosial ekonomi dapat mencakupi salah satu dari kriteria di atas atau termasuk kedua-duanya.

Ikhtiar untuk terpenuhinya usia harapan hidup masih ditemukan adanya beberapa kendala yang ditunjukkan oleh terjadinya fluktuasi pada dua indikator lainnya yaitu angka kematian ibu dan angka kematian bayi (lahir mati). Terlihat dalam tabel 2 bahwa tahun 2008 jumlah Angka Kematian
Ibu hanya 92 orang, sementara pada tahun 2012 mencapai 100 orang dengan pertumbuhan sebesar 2,11\% sedangkan angka kematian bayi pada tahun 2008 sebanyak 577 orang meningkat menjadi 763 orang pada tahun 2012, tumbuh sebesar 7,24\%. Tingginya angka kematian ini selain merupakan ketentuan Allah SWT, namun tidak dapat dilepaskan dari faktor-faktor yang datangnya dari perilaku Ibu hamil. Meskipun tidak diketahui secara pasti golongan masyarakat mana yang paling dominan mengalami musibah ini, namun dapat dikatakan bahwa faktor pendidikan dan latar belakang ekonomilah yang paling berpengaruh terhadap masalah ini. Faktor lainnya adalah masih kuatnya pengaruh adat dan budaya yang dianut, sehingga dalam menjalankan proses kehamilannya, Ibu hamil terkadang mengabaikan hal-hal yang bersifat rasional dan mengedepankan halhal yang bersifat irrasional. Ikhtiar pemerintah NTB untuk meningkatkan kualitas SDM-nya terus dilakukan dengan melakukan berbagai langkah-langkah strategis seperti Jamkesmas, Jaminan Persalinan, Revitalisasi Posyandu, Pemusatan Pelayanan Gizi Buruk, Rekrutmen Bidan dan Paramedik. Pembangunan fasilitas kesehatan milik Pemerintah baik dalam bentuk Rumah Sakit Provinsi yang berada di Pulau Sumbawa maupun Pulau Lombok telah memberikan hasil namun capaiannya belum optimal, sehingga diperlukan langkah strategis lain dan kerja keras untuk mewujudkan harapan tersebut.

Pembangunan bidang kesehatan dalam perspektif ekonomi Islam, mendapatkan skala prioritas. Tidak mungkin manusia dapat melakukan aktivitas pemenuhan kebutuhan dengan baik bila kesehatannya dalam keadaan tidak sehat atau sakit. Penekanan Islam untuk memelihara kesehatan tertuju pada kesehatan jasmani, kesehatan rohani maupun kesehatan sosial. Dalam AlQur'an terdapat ayat yang memerintahkan manusia untuk menjaga kesehatan baik yang berkaitan dengan aktivitas konsumsi maupun produksi juga dalam distribusi. Dalam 
aktivitas konsumsi Al-Qur'an melarang mengkonsumsi barang-barang yang kotor, haram baik yang berasal dari hewan maupun tumbuh-tumbuhan. Salah satu firman Allah terdapat dalam surat Abasa ayat 24, artinya Maka hendaklah manusia itu memperhatikan makanannya. Demikian halnya dalam melakukan proses produksi, dilarang untuk memproduksi barang-barang yang menghancurkan kesehatan seperti khamar dan sejenisnya, serta memproduksi barang yang mudharatnya lebih banyak dari manfaatnya seperti merokok, apalagi memproduksi barang yang haram, karena itu semua akan mengotori aspek kesehatan terutama kesehatan jasmani dan rohani. Berkaitan dengan kesehatan ini Rasulullah berdoa yang artinya Ya Allah, perkayalah diriku dengan ilmu, biasakanlah diriku dengan kasih sayang, muliakanlah diriku dengan katakwaan dan percantiklah diriku dengan kesehatan yang sempurna (HR. Ibun Al-Najar dari Ibnu Umar). Pada hadist lain Rasulullah bersabda Raihlah manfaat lima masa sebelum datangnya lima masa yaitu masa hidup sebelum matimu, masa sehat sebelum sakitmu, masa senggang sebelum sempitmu, masa muda sebelum tuamu dan masa kaya sebelum miskinmu (HR. Ibnu Al-Najar dari Ibnu Umar). Firman Allah dan hadist Nabi menekankan perlunya memelihara kesehatan terutama dari makanan dan minuman sebagai sumber tenaga. Untuk mewujudkan kesehatan lahir dan batin maka dianjurkan untuk mengkonsumsi makanan dan minuman yang halal dan (halalan), baik (thayyib) dan seimbang, tidak berlebihan (Zulmaizarna, 2009). Pada sisi pakaianpun, Islam telah memberikan petunjuk yang jelas tentang pemanfaatannya. Mengingat pakaian sebagai salah satu kebutuhan dasar, maka cara memperolehnyapun harus didasarkan pada aturan-aturan normatif yang telah ditentukan, agar tidak mengganggu keseha tan. Pemeliharaan kesehatan terutama dalam hal mengkonsumsi makanan, dimaksud kan untuk memberikan pemahaman kepada manusia terhadap keselamatan generasi pelanjut pewaris keturunan. Dalam membentuk generasi pewaris, supaya diberikan makanan yang halal dan baik, bukan makanan haram, karena akan berdampak pada proses pertumbuhan dari anak tersebut. Pemenuhan kebutuhan kesehatan baik dalam mengkonsumsi makanan maupun pakaian, juga tempat berlindung dan generasi pewaris merupakan implementasi dari maqashid syariah yaitu menjaga jiwa dan keturunan.

Langkah-langkah yang telah dilakukan oleh pemerintah Provinsi NTB untuk meningkatkan kualitas SDM di bidang kesehatan tidak terlepas dari aturan normatif yang telah digariskan oleh Islam. Peningkatan mutu kesehatan penduduk merupakan ikhtiar yang terus dilakukan melalui pendidikan gizi khususnya bagi ibu-ibu yang memilik balita gizi buruk, lebih menekankan pada pendekatan preventif dan promotif. Penekanan pada perbaikan gizi akan berdampak pada pertumbuhan kesehatan yang akan diikuti oleh perbaikan pola makan. Langkah-langkah untuk meminimalisir angka kematian bayi yang lahir merupakan ikhtiar untuk menjaga dan menciptakan generasi pewaris orang tuanya sebagaimana yang diuraikan dalam perspektif ekonomi Islam. Hal ini bisa direalisasikan, bila didukung oleh ketersediaan SDM di bidang kesehatan yang memiliki latar belakang pengetahuan umum dan agama. Sinergisitas pengetahuan ini akan berdampak pada kebiasaan masyarakat yang masih menganut sistem budaya yang bersifat tradisional.

\section{Kondisi Perekonomian}

Kondisi Perekonomian suatu daerah turut mempengaruhi tinggi rendahnya kualitas SDM yang berada di daerah tersebut, karena dengan kondisi perekonomian yang stabil suatu daerah akan mampu membangun daerahnya termasuk SDM. Peningkatan kualitas SDM terus dilakukan oleh pemerintah Provinsi Nusa Tenggara Barat, baik melanjutkan kebijakan-kebijakan yang berlaku secara nasional maupun kebijakankebijakan yang bersifat lokal. Kebijakankebijakan lokal yang dilakukan di antaranya peningkatan pendapatan melalui pembuka- 
an kesempatan kerja baru dengan membentuk 1000 wirausaha baru, adanya keterpaduan antara program PIJAR (Sapi, Jagung dan Rumput Laut), melanjutkan pengiriman TKI ke luar negeri melalui seleksi yang ketat, serta adanya nota kesepahaman antara
Bupati/Walikota se-NTB dalam upaya pemercepatan pengentasan kemiskinan di NTB. Dari beberapa usaha tersebut memberikan hasil sebagaimana terlihat dalam Tabel 3.

Tabel 3

Kondisi Perekonomian Provinsi Nusa Tenggara Barat Tahun 2008 - 2012 dilihat dari Beberapa Indikator

\begin{tabular}{|c|c|c|c|c|c|}
\hline \multirow{2}{*}{$\begin{array}{c}\text { Indikator } \\
\text { Perekonomian }\end{array}$} & \multicolumn{5}{|c|}{ Tahun } \\
\hline & 2008 & 2009 & 2010 & 2011 & 2012 \\
\hline $\begin{array}{l}\text { Jumlah } \\
\text { (orang) }\end{array}$ & 124.300 & 131.258 & 119.143 & 110.542 & 109.948 \\
\hline Tingkat Pengangguran & 6,13 & 6,25 & 5,29 & 5,33 & 5,26 \\
\hline Terbuka $(\mathrm{TPT}=\%)$ & & & & & \\
\hline $\begin{array}{l}\text { Pendapatan Perkapita } \\
(\mathrm{Rp})^{*} \text { ADHB }\end{array}$ & 5.698 .154 & 6.506 .598 & 7.198 .642 & 8.097 .491 & 9.106 .717 \\
\hline ADHK 2000 & 3.042 .066 & 3.235 .576 & 3.340 .115 & 3.492 .006 & 3.691 .617 \\
\hline Paritas Daya Beli (Rp) & 633.58 & 637.98 & 639.89 & 642.80 & 645.72 \\
\hline Kemiskinan Jiwa) & 1.068 .820 & 1.014 .745 & 972.300 & 896.200 & 828.330 \\
\hline Persentase (\%) & 24.49 & 22.88 & 21.58 & 19.67 & 18,02 \\
\hline
\end{tabular}

Pada Tabel 3 terlihat bahwa kinerja perekonomian dilihat dari beberapa indikator menunjukkan kemajuan yang menggembirakan, karena mengalami perubahan yang signifikan.

\section{a) Jumlah Penganggur dan Tingkat Pengangguran Terbuka}

Jumlah penduduk yang menganggur terus menurun kecuali pada tahun 2009 meningkat karena terjadinya krisis perekonomian global yang turut berdampak terhadap kinerja perekonomian NTB dan mencapai 109.948 orang pada tahun 2012 dengan pertumbuhan sebesar $-3,02 \%$. Penurunan jumlah penganggur ini secara otomatis diikuti oleh menurunnya tingkat pengangguran terbuka pada tahun 2012 mencapai 5,26\% dengan pertumbuhan $-3,75 \%$. Hal ini mengindikasikan, bahwa selama tahun 2008-2012 pemerintah NTB telah kesempatan atau membuka peluang kerja bagi penduduk untuk memasuki pasar kerja, baik pada lembaga-lembaga peme- rintah atau perusahaan-perusahaan milik daerah, serta adanya kebijakan memberikan ijin usaha kepada pihak swasta untuk membuka usaha baru (Investasi) di NTB sehingga memberikan peluang pada penduduk NTB untuk menjadi tenaga kerja pada usaha-usaha swasta tersebut. Terbukanya kesempatan kerja diiringi dengan menurunnya jumlah pengangguran berdampak positif bagi proses pembangunan daerah NTB. Dampak negatif pengangguran seperti kestabilan kondisi sosial dan ekonomi dapat terjaga, angka kriminalitas dapat dikurangi serta menurunnya jumlah penyandang masalah kesejahteraan sosial diantaranya Gelandangan dan Pengemis (Gepeng), meskipun pada akhir-akhir ini Gepeng dijadikan suatu pekerjaan atau profesi bagi yang melakoninya. Bertambahnya kesempatan kerja serta menurunnya jumlah pengangguran, merupakan salah satu ciri kualitas SDM mengalami peningkatan. 
Pengangguran dalam ekonomi Islam tidak diberikan toleransi sedikitpun, karena akan menghancurkan ciri kemanusiaannya. Manusia dengan akal yang dimiliki, kemudian memperoleh ilmu pengetahuan harus melakukan pekerjaan dalam bentuk apapun sepanjang mengikuti aturan dalam AlQur'an dan Al-Hadist. Menurut Qardhawi (2005) pengangguran akan membawa dampak buruk terhadap individu masyarakat antara lain (1). Secara ekonom; tidak mempunyai pemasukan ataupun penghasilan; (2). Secara kesehatan; akan mengurangi gerak tubuh dan langkah kaki; (3). Secara kejiwaan; akan membuat seseorang hidup dalam kekosongan; (4). Secara kemasyarakatan; menimbulkan iri dan dengki atas keberhasilan orang lain. Dalam internal keluarga, dampak pengangguran ini akan membawa malapetaka bagi keluarga baik berkaitan dengan hubungan personal antara suami dan isteri, juga bagi keturunannya, yang bermuara pada terciptanya SDM yang berkualitas rendah. Oleh karenanya, ekonomi Islam melalui salah satu prinsipnya kebebasan ekonomi, berarti bahwa seseorang individu telah diberi kebebasan oleh Allah untuk mencari harta (bekerja), memilikinya, menikmatinya serta membelanjakan sesuai dengan kehendaknya. Prinsip ini bermakna kebebasan untuk memilih profesi, bisnis, lapangan kerja maupun dalam mencari nafkah. Namun Islam tidak memberi kebebasan tak terbatas dalam lapangan ekonomi (Chaudry, 2012).

\section{b). Pendapatan Perkapita dan Paritas Daya Beli}

Kesempatan kerja yang bertambah diiringi dengan menurunnya jumlah pengangguran berimplikasi pada peningkatan pendapatan yang diperoleh masyarakat dan berpengaruh pada perubahan pendapatan perkapita. Hal ini terlihat dalam tabel3 di atas, bahwa pendapatan per kapita selama tahun 2008-2012 mengalami peningkatan hingga mencapai $59,82 \%$ berdasarkan harga berlaku dan sebesar 21,53\% berdasarkan harga kons- tan (tidak termasuk sub sektor pertambangan non migas). Peningkatan ini tidak terlepas dari keberhasilan pemerintah NTB menaikkan peran sektor-sektor PDRB yang mampu melakukan berbagai terobosan dalam mengembangkan hasil produksinya yang berdampak pada tingginya tingkat pendapatan. Peningkatan pendapatan perkapita akan mempengaruhi kinerja indikator lainnya yaitu semakin tingginya kemampuan masyarakat untuk mengkonsumsi (Paritas daya beli) barang yang menjadi kebutuhannya. Terlihat dalam tabel 3, Paritas Daya Beli masyarakat Nusa Tenggara Barat Tahun 2008 sebesar Rp 633,58 terus mengalami peningkatan hingga mencapai $\mathrm{Rp}$ 645,72 . Ini berarti bahwa pada tahun 2008 penduduk memerlukan sekitar Rp 635,58 ribu untuk memenuhi kebutuhan konsumsinya dan pada tahun 2012 meningkat menjadi Rp 645,72 ribu, tumbuh sebesar 0,48\%. Peningkatan ini diharapkan penduduk Nusa Tenggara Barat akan berada dalam kondisi kehidupan yang layak, atau penduduk Nusa Tenggara Barat akan meningkat kualitasnya setidaknya jauh berada di atas garis kemiskinan.

\section{c). Kemiskinan}

Kemiskinan penduduk hingga saat ini masih menjadi tugas berat pemerintah dan menjadi prioritas utama dalam tahapan pembangunan Indonesia. Permasalahan kemiskinan yang cukup kompleks membutuhkan intervensi semua pihak secara bersama dan koordinasi (Nugroho dan Suprianto, 2010). Diakui kinerja pemerintah untuk menurunkan penduduk miskin telah menuai hasil yang menggembirakan, namun pada bulan September 2012 masih berjumlah 28,59 juta jiwa atau sebesar 11,66\% merupakan suatu jumlah yang masih sangat besar. Karakteristik kemiskinan di Indonesia secara umum adalah (Stamboel, 2012) mayoritas rumah tangga miskin menggantungkan hidupnya di sektor pertanian, mayoritas petani gurem/subsisten, disparitas tingkat kemiskinan yang tinggi antara desa dan kota, antar provinsi, domoniasi belanja makanan terhadap garis kemiskinan, ber- 
kumpul di sekitar garis kemiskinan dan bersifat multidimensi. Oleh karenanya langkah-langkah strategis yang pernah dilakukan maupun yang sedang dilakukan diikhtiarkan untuk tetap mengurangi penduduk dari kemiskinan.

Penduduk miskin di Nusa Tenggara Barat juga terjadi penurunan selama tahun 2008-2012. Seiring dengan semakin tinggi pendapatan perkapita akan merangsang terjadinya peningkatan konsumsi yang berdampak pada tercapainya pemenuhan kebutuhan pokok minimal. Pada sisi lain, peningkatan pendapatan per kapita akan berdampak pada penurunan penduduk miskin karena pendapatan tersebut berada di atas ambang batas garis kemiskinan. Bila pendapatan perkapita pada tahun 2012 di hitung per bulan mencapai sebesar Rp 758.893,- (ADHB) dan Rp 307.635,- (ADHK) sementara batas garis kemiskinan pada tahun tersebut sebesar Rp 215.740,-.. Kendati demikian, jumlah penduduk miskin pada tahun 2012 masih tersisa 828.330 jiwa atau sekitar 18,02 \% dari total penduduk NTB. Kondisi ini terjadi karena pendapatan perkapita hanya menggambarkan pendapatan dari pemilik faktor produksi, padahal kenyataannya tidak semua masyarakat dapat berpartisipasi dalam proses produksi, sehingga PDRB per kapita hanya memberikan gambaran secara umum, tanpa mencerminkan distribusi pendapatan antara masyarakat baik yang memiliki maupun tidak memiliki faktor produksi (BPS NTB, 2009).

Perubahan sejumlah indikator ekonomi di atas, tidak dapat dilepaskan dari kinerja perekonomian yang dilihat dari pertumbuhan ekonominya. Pertumbuhan ekonomi yang diharapkan adalah terciptanya pertumbuhan ekonomi yang berkualitas yaitu pertumbuhan ekonomi yang mampu menyediakan kesempatan kerja yang cukup besar yaitu pertumbuhan ekonomi yang dipicu oleh banyaknya investasi yang bersifat padat tenaga kerja, bukan yang bersifat pada modal (Arsyad, 2010). Bagi pemerintah provinsi NTB, peningkatan pertumbuhan ekonomi dari tahun ke tahun merupakan suatu keniscayaan, karena merupakan salah satu indikator dari keberhasilan daerah ini membangun perekonomian daerahnya. Pertumbuhan ekonomi Nusa Tenggara Barat selama tahun 2008-2012 (Gambar 3).

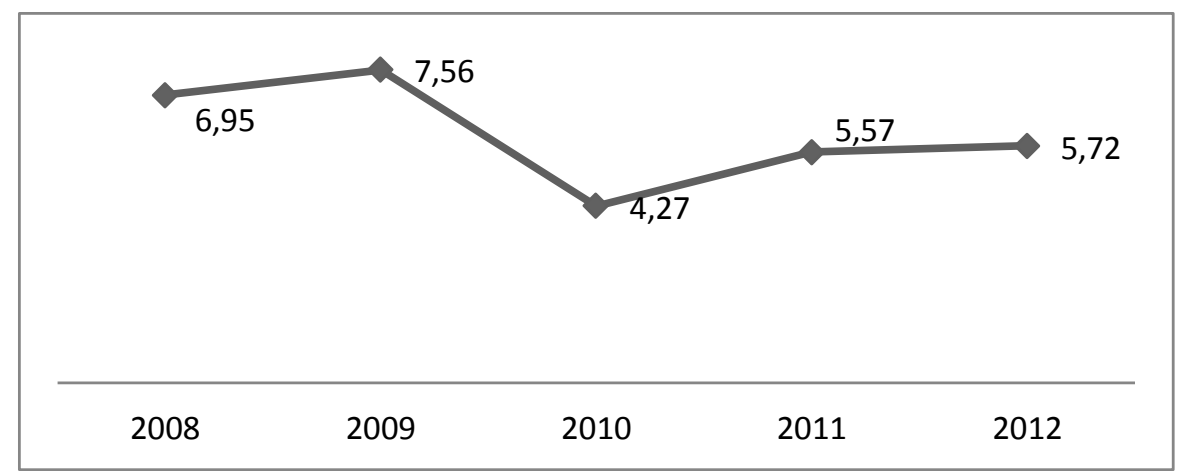

\section{Gambar 3 \\ Pertumbuhan Ekonomi Propinsi Nusa Tenggara Barat Tahun 2008-2012 atas Dasar Harga Konstan Tahun 2000 tidak termasuk Sub Sektor Pertambangan Non Migas}

Berdasarkan Gambar 3 terlihat bahwa pertumbuhan ekonomi NTB terjadi fluktuasi dengan capaian tertinggi pada tahun 2009 menurun secara berarti pada tahun 2010 kemudian meningkat dengan pertumbuhan melambat. Rata-rata Pertumbuhan ekonomi dalam kurun waktu tersebut mencapai 6,0 \% dan tergolong dalam pertumbuhan ekonomi dengan kualitas rendah. Rendahnya kualitas pertumbuhan ekonomi juga dapat dilihat 
dari pertumbuhan sektor-sektor ekonomi yang lebih tinggi terjadi pada sektor-sektor padat modal (non-tradeable) dibanding pertumbuhan sektor-sektor pada karya (tradeable). Pada tahun 2012 pertumbuhan sektor padat modal (non-tradeable) seperti Listrik, Gas dan Air bersih mencapai 7,41\%, Bangunan sebesar $4,79 \%$, Perdagangan, Hotel dan Restoran mencapai 9,29\% Pengangkutan dan Komunikasi mencapai 6,39\% serta Keuangan, Persewaan dan Jasa Perusahaan mencapai $8,64 \%$. Sedangkan sektor-sektor padat karya (tradeable) seperti sektor peranian hanya tumbuh $4,57 \%$, pertambangan dan penggalian $-26,98 \%$ serta industri pengolahan hanya tumbuh sebesar 3,59\%. Hal ini mengindikasikan bahwa pertumbuhan ekonomi yang terjadi di Nusa Tenggara Barat bahkan di tingkat Nasional masih didominasi oleh sektor yang padat modal dengan penyerapan tenaga kerja yang relatif lebih kecil dibanding dengan sektor padat karya yang mengalami pertumbuhan ekonomi yang melambat. Dampaknya adalah terjadi penurunan penyerapan tenaga kerja pada sektor padat karya, berimbas pada menurunnya pendapatan yang kembali mendongkrak penduduk menuju ke garis kemiskinan atau berada di bawah garis kemiskinan. Menurut Winoto dan Siregar (2006), melalui program padat karya masyarakat akan berpartisipasi aktif dalam pembangunan dan pemeliharaan infrastruktur sehingga lapangan kerja produktif akan terbuka yang akan berdampak pada peningkatan ekonomi rakyat di sektor riilnya. Akhirnya berdampak pada pengurangan kemiskinan dan pengangguran serta meningkatkan daya beli masyarakat. Oleh karenanya menurut Stamboel (2012), untuk meraih sustainable development yang berkualitas dan berdampak luas, harus merubah orientasi pembangunan dari paradigma pertumbuhan (growth oriented) yang mengarah pada pertumbuhan ekonomi yang tinggi disertai pemerataan (growth with equity), mengikutsertakan sebanyak mungkin penduduk (inclusive growth) yang ditopang oleh pembangunan SDM (people centered development). Lebih lanjut dikatakan, pertumbuhan ekonomi yang berkualitas dan inklusif akan menjadi landasan penting bagi pengentasan kemiskinan dan akan bermanfaat bagi rakyat miskin untuk mendorong peningkatan pendapatan dan distribusinya.

Pengentasan penduduk miskin dalam ekonomi Islam jauh-jauh hari telah dibahas, karena sebagaimana halnya dengan pengangguran, kemiskinan tidak mendapat tempat dan tidak diberikan toleransi karena disadari bahwa kemiskinan akan selalu ada dalam kondisi dan waktu yang berbeda. Sebagaimana yang dikatakan Ibrahim (2007) bahwa kemiskinan merupakan sesuatu yang sama tuanya dengan usia kemanusiaan itu sendiri. Sehingga ketika Al-Qur'an diturunkan kepada Nabi Muhammad SAW (611-632 M), masyarakat Makkah dan Madinah serta kawasan sekitarnya juga menghadapi problem kemiskinan. Bahkan perhatian tersebut dimulai pada priode awal yaitu priode makky (priode sebelum Nabi Muhammad SAWhijrah ke Madinah pada tahun 622 M) yang dicerminkan oleh berbagai ayat dalam surat-surat pendek seperti surat Al-Maun, Al-Balad, Al-Fajar dan sebagainya.

Perhatian Islam terhadap kemiskinan sangat penting karena berdampak pada kualitas individu, keluarga maupun masyarakat (SDM) yang rendah. Proses kehidupan yang serba kekurangan, pemenuhan kebutuhan hidup (materi) yang terbatas berimplikasi pada lemahnya tenaga untuk bekerja, kondisi kesehatan yang serba kekurangan, peluang untuk mengenyam pendidikan meskipun pada jenjang pendidikan dasar terbatas bahkan tidak mampu, dan lain-lainnya. Maka jadilah kemiskinan menjadi permasalahan sosial, penyandang kemiskinan (orang miskin) akan menjadi beban masyarakat dan mereka dibiarkan menjalani kehidupannya menurut cara dan kehendaknya, maka terciptalah SDM yang tidak berkualitas. Kualitas ini semakin berkurang manakala sebahagian besar orang miskin tidak lagi mengenal eksistensi dirinya, tidak lagi melaksanakan ajaran agamanya yang menjadikan kedudukannya sebagai manusia 
menjadi umat yang tidak terhormat (terhina), sehingga aspek moral dan akhlak sudah terkikis. Maka lengkaplah kemiskinan yang disandang tidak hanya kemiskinan dari aspek materi tetapi kemiskinan mental spritual (rohani). Menurut Arraiyah (2007) kemiskinan rohani/jiwa adalah sifat jiwa yang buruk dan tercermin dalam bentuk sikap negatif, seperti rendah diri atau kehinaan, kehilangan gairah atau pesimis, dan perasaan tidak puas dengan apa yang diperolehnya. Sebelumnya Danim (2004) mengatakan bahwa kemiskinan non-material (nirmateri) adalah kemiskinan yang ditandai oleh prilaku mengabnormalkan normalitas atau sebaliknya menormalkan abnormalitas.

Kemiskinan juga bisa terjadi disebabkan oleh sistem ekonomi yang sedang berjalan. Pada saat ini sistem ekonomi yang sedang berjalan (konvensional) dengan jargon Globalisasi tengah merambah aktivitas kehidupan manusia di seantero jagad ini. Berbagai sistem ekonomi konvensional terutama kapitalis, liberalis maupun neoliberalis telah berkotribusi besar terhadap penciptaan kemiskinan baik secara mikro maupun makro. Slogan untuk mewujudkan kesejahteraan masyarakat yang didengungkan tidak kunjung tiba bahkan semakin lari menjauh, justru kemiskinan semakin merajalela dan berjalan beriring dengan sistem ekonomi konvensional. Pencapaian keuntungan maksimum, pemenuhan kebutuhan individu, disparitas pendapatan yang semakin melebar, pengangguran semakin bertambah, jerit tangis penduduk miskin karena kelaparan dan keterbatasan akses semakin tampak, pengurasan SDA yang tidak kendali demi sebuah nama investasi pada negaranegara kaya SDA tapi miskin SDM semakin terkuak, ketidak adilan dalam alokasi pendapatan dan lain-lain peristiwa yang justru menyuburkan kemiskinan. Jadilah sistem ekonomi ini menjadi sistem yang memberikan kekayaan yang melimpah pada sekelompok kecil orang tetapi menyengsarakan sebahagian besar umat manusia. Jadilah SDM semakin tidak berkualitas bahkan semakin menipiskan serta melunturkan nilai-nilai kemanusiaannya. Kemiskinan berdampak buruk terhadap pengembangan SDM disebabkan sedikitnya produktifitas orang miskin; karena orang miskin pada umumnya lebih sedikit dari pada orang kaya dalam pemenuhan makanan, kesehatan, pengajaran dan pelatihan. Pada sisi lain, kemiskinan juga berdampak negatif bagi produktifitas masyarakat karena tersebarnya tindak kriminal dan keguncangan keamanan dan ketrentraman, terlebih jika kesadaran agamanya lemah. Oleh karena itu, terapi terhadap problem kemiskinan akan meminimalisir penyia-nyiaan SDM ini dengan cara memberikan perlindungan sosial terhadap orang-orang miskin penjamin hidup mereka dan meningkatkan taraf hidup mereka dengan andil secara aktif dalam merealisasikan pengembangan ekonomi (AlHaritsi, 2006). Di samping itu, usaha untuk memberantas kemiskinan haruslah mengadopsi pendekatan-pendekatan makro (konprenhensif) dan holistic, yang tidak saja menuntut partisipasi dan peran aktif golongan miskin, tetapi juga melibatkan peran aktif pemerintah dan masyarakat pada umumnya (Majid, 2011). Mengacu pada berbagai data sebagai indikator Pembangunan Manusia yang berkualitas di atas, maka dapat diketahui bahwa Indeks Pembangunan Manusia di Nusa Tenggara Barat masih berada pada posisi yang belum menggembirakan. Meskipun dalam ikhtiarnya, pemerintah Provinsi Nusa Tenggara Barat telah mampu melakukan percepatan dan perbaikan terhadap beberapa Indikator IPM, bahkan termasuk dengan prestasi membanggakan seperti penurunan penduduk miskin yang masuk dalam 10 besar nasional. Keberhasilan tersebut telah mampu menghantarkan posisi NTB berada pada golongan kesejahteraan menengah atas pada tahun 2012. Namun sayang, prestasi tersebut belum mampu menghantarkan posisi NTB bergeser pada posisi 32 dari 33 provinsi yang berada di Indonesia.

Peningkatan nilai IPM NTB dari tahun 2008-2012 (Gambar 4) mencerminkan terjadi 
nya perubahan dalam kualitas kehidupan manusia dilihat dari berbagai Indikator. Dengan posisi NTB masih berada di nomor 2 dari bawah mendorong para pengambil kebijakan serta pelaksana administratif dae rah ini untuk terus memacu kualitas kehidupan SDMnya. Hal ini dapat dilaksanakan, bila segala potensi SDA ditopang oleh ketersediaan SDM yang tersedia saat ini, akan mampu mewujudkan harapan tersebut. Peningkatan IPM NTB dilakanakan secara simultan pada tiga komponen IPM dan tidak dilaksanakan secara parsial. Hal utama yang dilakukan adalah pelaksanaan secara simultan antara tingkat pendidikan dan kesehatan wanita, karena kedua faktor ini sangat menentukan kualitas SDM. Hasil penelitian Utami (2009) di kota Surabaya menemukan bahwa kemiskinan merupakan faktor utama yang menyebabkan meningkat nya gizi buruk sejak awal tahun 2008. Pendidikan wanita tidak mempengaruhi dalam penurunan tingkat kemiskinan walaupun dapat mempengaruhi tingkat pendapatan seorang wanita sekalipun. Sebelumnya penelitian Elfrindri dan Saputra (2005) di Sumatera Barat menemukan bahwa pendidikan kepala rumah tangga yang paling beresiko masuk ke dalam katagori miskin adalah yang berpendidikan SD dan SLTP dan rumah tangganya dikepalai oleh wanita.

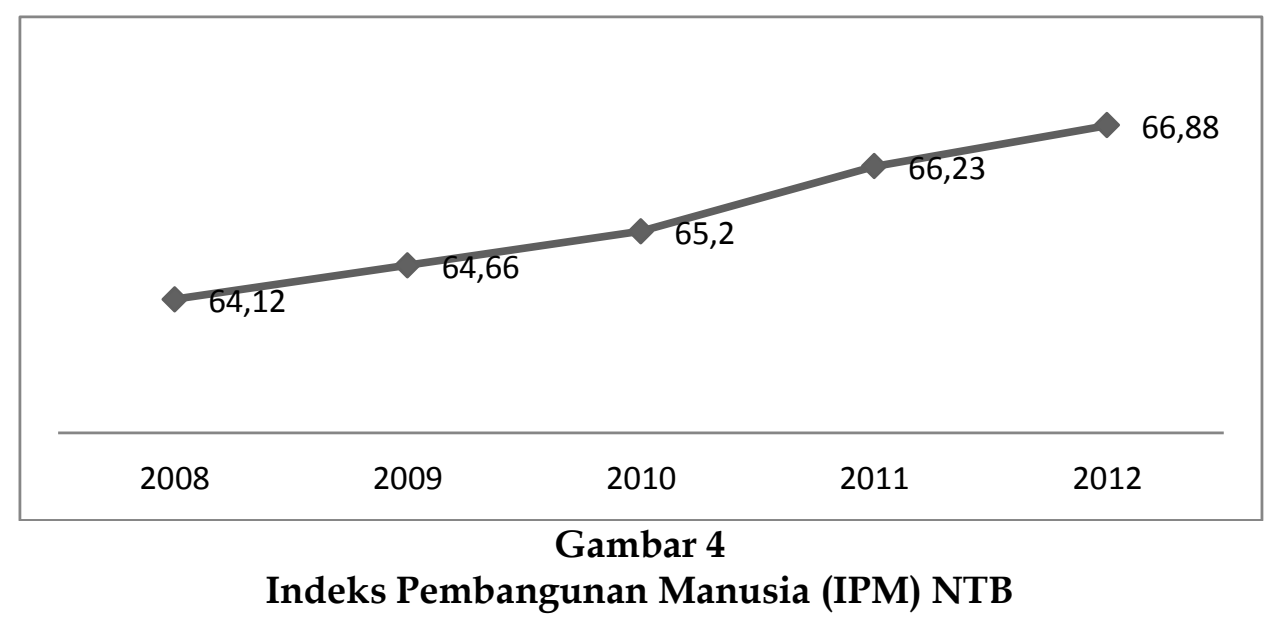

Ikhtiar yang dilakukan oleh pemerintah NTB untuk menaikkan kualitas SDM dari aspek pendidikan, kesehatan, kondisi perekonomian, kemiskinan maupun Indeks Pembangunan Manusia (IPM) sejak tahun 2008-2012 menunjukkan perubahan yang positif meskipun belum mencapai usaha yang optimal. Hal itu terus menjadi kebijakan yang dilakukan oleh pemerintah NTB dalam proses pembangunan, mengingat pentingnya ketersediaan SDM yang berkualitas untuk mengisi proses pembangunan berkelanjutan.

Ekonomi Islam memiliki prinsip Ketauhidan, Keadilan, Kebersamaan, dan Keseimbangan (Pertengahan). Ekonomi Islam bertujuan menghantarkan manusia memenuhi kebutuhannya guna mencapai ke sejahteraan hakiki yang tidak hanya di dunia juga di akhirat (al-falah). Falah berarti orang yang mempersiapkan lahan dengan segala kondisi yang dibutuhkan untuk berkembangnya benih, sehingga karena kondisi tanah dan air yang mendukung benih itu menjadi tanah yang luas dan menguntungkan (Arif, 2007). Falah dapat terwujud bila kebutuhan menimbulkan maslahah yaitu segala bentuk keadaan, baik material maupun non material yang mampu meningkatkan kedudukan manusia sebagai makhluk yang paling mulia (P3EI, 2008), melalui terciptanya tujuan syariat yaitu terpeliharanya kebutuhan akan agama (hifzh al-din), jiwa (hifzh al-nafs), akal atau ilmu (hifzh al-aql), keturunan (hifzh al-nasl) dan harta (hifzh al-mal) yang merupakan kebutuhan dasar yang 
harus dipenuhi (darruriyah). Jika ini sudah terpenuhi dilanjutkan dengan pemenuhan kebutuhan lainnya yaitu hajiyah dan tahsiniyah yang bersifat penyempurna dan pelengkap. Jika manusia sudah mampu menjaga sekaligus memenuhi kebutuhan darruriyahnya maka manusia tersebut digolongkan sebagai manusia berkualitas yaitu manusia yang dapat hidup bahagia di dunia dan akhirat. Jika tidak dapat memenuhi salah satu kebutuhan tersebut, sudah dipastikan tidak akan mampu menggapai kebahagiaan yang menghantarkan manusia tersebut berada dalam kekurangan dan tidak berkualitas.

Ajaran yang paling fenomenal dalam Islam berkaitan dengan implikasi prinsip keadilan, kebersamaan dan persaudaraan serta dalam keseimbangan (pertengahan) salah satunya adalah distribusi harta dari orang yang mampu kepada orang yang tidak mampu. Dalam konteks ini, ekonomi Islam memberikan ruang kepada individu untuk bekerja sesuai kemampuannya agar memperoleh penghasilan guna memenuhi kebutuhannya. Tetapi dari pendapatan dan harta yang diperolehnya terdapat hak orang lain termasuk orang fakir dan miskin. Dalam AlQur'an banyak ayat yang memerintahkan untuk mendistribusikan harta dan diperuntukkan bagi orang yang tidak mampu bahkan orang yang mampu sekalipun ketika dihadapkan dengan suatu musibah atau cobaan. Ekonomi Islam mengedepankan adanya solidaritas sosial melalui jaminan sosial untuk menghilangkan adanya diskriminasi dari orang yang mampu terhadap orang yang tidak mampu yang akan membentuk keadilan sosial. Dalam Al-Qur'an, keadilan yang terkait dengan makna sosial paling tidak ada tiga (Kamil, 2011) yaitu persamaan di depan hukum (QS,.4;58); keseimbangan atau tidak adanya ketimpangan sebagai asas alam dan sosial (QS. 16; 3; 82, 67; $67 ; 3)$ serta tidak adanya kezaliman sosial (proporsional dan memberikan hak kepada pemiliknya (QS. 4: 135; 60; 8). Keadilan sosial akan membawa ketakwaan (QS 5, 8) dan ketakwaan akan membawa kemamuran (QS.
7;96). Bentuk-bentuk jaminan sosial dalam Islam sangat banyak baik perintah wajib (Zakat) maupun sunnah seperti infaq, shadaqah, wakaf, kurban dan lainnya. Bentuk jaminan sosial atau kepedulian sosial ini akan mampu mengangkat harkat dan martabat kemanusiaan, sekaligus kualitas SDMnya. Semuanya dimaksudkan agar harta kekayaan tidak menumpuk pada segolongan atau segelintir orang (Qs. Al-Hasyr, 17) yang akan menimbulkan macetnya distribusi harta lantaran adanya sifat pelit dan kikir dalam jiwa seseorang yang bermuara pada timbulnya manusia serakah, rakus dan sombong. Sifat ini merupakan ciri manusia yang tidak berkualitas meskipun secara materi tergolong kaya. Pemenuhan kualitas sumberdaya manusia dalam kajian ekonomi dengan beberapa indikator merupakan pencapaian maqashid syariah dalam menjaga harta dan keturunan.

Perkembangan positif yang dicapai oleh propinsi NTB dalam memperbaiki kondisi perekonomiannya menunjukkan keadaan yang menggembirakan meskipun secara optimal belum terwujud. Perbaikan kualitas ekonomi yang dilihat dari beberapa indikator di atas, merupakan wujud dari visi berupa perwujudan manusia beriman dan berdaya saing. Pembangunan ekonomi yang telah dilaksanakan terilhami dari cara dan strategi ekonomi Islam dalam membangun manusia sebagai subyek sekaligus obyek pembangunan. Prinsip pembangunan yang berkeadilan, dijiwai semangat kebersamaan dan tolong menolong, baik dalam bentuk materi maupun non materi serta adanya keberpihakan kepada kaum lemah telah menghantarkan daerah ini mampu mengangkat harkat dan martabat serta kualitas SDMnya. Dengan tetap mengacu pada prinsip yang disebutkan di atas, disertai landasan keimanan yang kokoh, daerah ini mampu menurunkan angka pengangguran dan membuka kesempatan kerja baru, meningkatkan pendapatan yang berimplikasi pada peningkatan daya beli, penduduk miskipun mengalami penurunan. Melihat visi dan hasil yang telah dicapai pemerintah NTB 
selama periode analisis, telah bersinergi dengan landasan ideal dalam perspektif Ekonomi Islam, meskipun belum sesuai harapan.

Hasil yang ingin dicapai dalam peningkatan kualitas SDM, dari beberapa aspek yang dianalisis, tidak hanya sematamata tertuju pada aspek jasmaniah melainkan juga pada aspek rohaniah. Hal ini tercermin dari beberapa visi pemerintah NTB yaitu mengembangkan masyarakat madani yang berakhlak mulia, pelayanan pendidikan dan kesehatan yang berkeadilan, maka aspek jasmani dan rohani dilaksanakan secara bersama. Oleh karenanya, SDM yang berkuliatas adalah SDM yang mampu memadukan aspek batiniah dan rohaniah atau sepritual. SDM yang tidak disertai dengan kesetiaan kepada nilai-nilai keagamaan, hanya akan membawa manusia ke arah pengejaran kenikmatan duniawi atau hedonisme belaka (Mubarok, 2012). Berkaitan dengan kondisi SDM yang masih relatif rendah, pendidikan belum dinikmati oleh semua penduduk, kemiskinan dan pengangguran yang masih banyak, konsep pembangunan berkualitas harus memberikan peluang terciptanya keadilan sosial, utamanya kepada masyarakat yang tergolong mampu guna memberikan jaminan sosial dengan lebih mengimplementasikan ajaran-ajaran agama yang berpihak kepada orang tidak mampu.

Kualitas SDM dalam perspektif Islam yang sebagiannya telah diuraikan di atas, setidaknya telah diimpelementasikan oleh pemerintah NTB dengan memasukkan unsur keimanan dan berdaya saing di dalam visi pembangunan, yang pada akhirnya diharapkan akan terwujud masyarakat sejahtera dunia dan akhirat. Memasukkan unsur keimanan dalam visi pembangunan NTB, diharapkan akan membawa dampak positif terhadap perkembangan kualitas SDM, karena ajaran keimanan mengacu kepada agama yang dianut oleh penduduk NTB. SDM yang menjadi harapan ekonomi Islam adalah SDM yang memiliki akhlaq mulia dan baik. Dengan akhlak yang baik
SDM akan mampu menjabarkan tugasnya sebagai khalifah sekaligus hamba Allah di bumi. Akhlak tidak hanya masalah batiniah, juga meliputi masalah rohaniah yaitu terisinya hati seseorang dengan sifat utama, seperti bertanggung jawab, adil, sabar, pemaaf dan terhindar dari sifat yang merusak seperti sombong, irihati, dengki dan lainnya (Zulmaizarna,2009). Ciri SDM yang berkualitas itulah yang hendak dituju oleh pemerintah NTB untuk mengisi proses pembangunan yang berkelanjutan. Meskipun hasil yang dicapai dalam analisis ini belum sepenuhnya terealisasi, karena dalam kehidupan penduduk NTB masih didapatkan perilaku menyimpang dari ciri ideal tersebut, baik dilakukan oleh SDM yang memiliki kualitas pendidikan rendah maupun tinggi, kaya maupun miskin.

\section{SIMPULAN DAN SARAN Simpulan}

Berdasarkan hasil pembahasan yang berkaitan dengan kualitas SDM di Nusa Tenggara Barat, dapat ditarik beberapa simpulan sebagai berikut:

1. Jumlah penduduk yang tergolong buta huruf mengalami penurunan, pada tahun 2012 sudah mencapai 83,38\% dan masih tersisa $16,62 \%$. Rata-rata lama sekolah pada tahun 2012 mencapai 7,19 tahun artinya pada saat itu penduduk NTB baru menduduk kelas I SMP mengalami peningkatan dibanding pada tahun 2008 yang baru mencapai 6,70 tahun. Kondisi ini masih di bawah program pemerintah dengan wajib belajar 9 tahun.

2. Usia harapan hidup penduduk meningkat dari 61,50 tahun pada tahun 2008 menjadi 61,70 tahun pada tahun 2012. Angka Kematian Ibu (AKI) masih tergolong tinggi, Jumlah bayi yang lahir mati selalu mengalami peningkatan. Dilihat dari indikator kesehatan, kualitas SDM NTB masih relatif rendah karena masih tingginya angka kematian bayi maupun kematian ibu sebagai 
dampak masih rendahnya pengetahuan tentang pemeliharaan aspek kesehatan serta masih minimnya fasilitas kesehatan yang tersedia.

3. Jumlah Pengangguran selama tahun 2008-2012 terus menurun, Tingkat Pengangguran Terbuka mencapai 5,26\%. Hal ini berdampak meningkatnya pendapatan per kapita yang telah mampu meningkatkan daya beli masyarakat NTB. Jumlah penduduk miskin tahun 2008 - 2012 terus menurun. Kondisi ini mengindikasikan bahwa pemerintah NTB telah mampu meningkatkan kualitas penduduk melalui peningkatan pemenuhan kebutuhan minimalnya.

4. Pertumbuhan ekonomi Nusa Tenggara Barat selama tahun 2008-2009 rata-rata mencapai $6.0 \%$. Pertumbuhan ini masih belum berkualitas karena belum mampu menopang peran sektor-sektor padat karya (tradeable) lebih besar dibanding dengan sektor-sektor padat modal (nontradeable).

5. SDM berkualitas dalam ekonomi Islam adalah yang memiliki ilmu pengetahuan, sehingga menuntut ilmu merupakan kewajiban yang harus dilakukan sejak lahir hingga menjelang kematian. SDM yang mampu mengimpliklasikan ilmunya dengan merujuk pada aturan normatif yang ada dalam Al-Qur' an dan Al-Hadist .

6. Aspek kesehatan, dalam ekonomi Islam harus dilakukan dengan kondisi yang bersih (konsumsi, produksi, distribusi) maupun dalam aktivitas non ekonomi, karena kesehatan akan menghantarkan terciptanya kestabilan emosional dan kesucian jiwa dan penyelamatan generasi pewaris keturunan.

7. Ekonomi Islam mewajibkan umat manusia untuk bekerja agar dapat memperoleh penghasilan, yang dapat dimanfaatkan untuk memenuhi kebutuhan diri dan keluarganya. Sebagiannya ada hak orang lain yang didistribusikan melalui distribusi harta baik yang wajib maupun sunnah. Hal ini sebagai wujud untuk menciptakan prinsip keadilan, kebersamaan dan persaudaraan, keseimbangan serta jaminan sosial, agar manusia tidak terkungkung dalam kemiskinannya.

8. SDM yang berkualitas dalam perspektif ekonomi Islam adalah sumber daya yang mampu memelihara dan menjaga kebutuhan agama, Jiwa, Akal (Ilmu), Keturunan dan harta (Maqashid syariah) agar tercapai falah yaitu kebahagian di dunia dan di akhirat melalui pemenuhan kebutuhan yang bersifat pokok (dharuriyah). Ciri lainnya adalah tersirat dari sabda nabi Muhammad SAW yang menyuruh manusia menjaga hidup, sehat, muda, kesempatan dan harta (kualitas) sebelum datangnya kematian, sakit, tua, kesempitan dan kemiskinan (tidak berkualitas).

9. Kualitas SDM dalam di NTB telah menerapkan unsur-unsur yang berada di dalam perspektif ekonomi Islam, namun hasil yang diperoleh belum mencapai kondisi ideal, karena masih terdapat perilaku-perilaku yang menyimpang dari tujuan tersebut.

\section{Saran}

Berdasarkan simpulan di atas, dapat diberikan saran-saran sebagai berikut:

1. Kepada Pemerintah Provinsi NTB agar terus meningkatkan kualitas penduduk, dengan menyelaraskan berbagai kebijakam yang benar-benar dapat memberikan ruang kepada penduduk untuk mengembangkan potensi dan kemampu annya, baik melalui pendidikan formal maupun non formal.

2. Memberikan pemahaman secara berkesinambungan kepada penduduk yang telah membina rumah tangga maupun belum, terutama kaum perempuan untuk memperhatikan berbagai aspek yang berkaitan dengan proses kehamilan sejak awal hingga menjelang melahirkan, sehingga dapat meminimisasi 
angka kematian terkecuali sudah merupakan kehendak dan takdir Allah SWT.

3. Perlu ditekankan pada peningkatan peran sektor-sektor padat karya guna menuju pertumbuhan ekonomi yang berkualitas sehingga akan memberikan dampak terhadap berbagai aspek yang berkaitan dengan proses kehidupan penduduk di Nusa Tenggara Barat.

4. Hendaknya menyandingkan kebijakankebijakan yang ditempuh dengan aspek-aspek yang dikedepankan oleh ekonomi Islam dalam ikhtiar meningkat kan kualitas SDM dengan memberikan peran maksimal pada pihak-pihak terkait terutama yang berkaitan dengan penggalian potensi dana umat yang belum dimanfaatkan secara optimal.

\section{DAFTAR PUSTAKA}

Al-Qur'an dan Al-Hadist

Aedy. H. 2011. Teori dan Aplikasi Ekonomi Pembangunan Dalam Islam, Sebuah Studi Komparasi. Graha Ilmu. Yogyakarta.

Al-Haritsi, J. B. A. 2006. Fikih Ekonomi Umar bin Al-Khattab. Khalifa. Jakarta.

Arraiyah, M. H. 2007. Meneropong Fenomena Kemiskinan, Telaah Perspektif Al-Qur'an. Pustaka Pelajar. Yogyakarta.

Arsyad, L. 2010.Ekonomi Pembangunan. Unit Penerbit dan Percetakan STIM YKPN. Yogyakarta.

Arif, S. 2007. Need Assestmen SDM Ekonomi Islam, La-Riba, Jurnal Ekonomi Islam 1(1):11-26.

Aziz, A.dan M. Ulfah.2010. KapitaSelekta Ekonomi Islam Kontemporer. Alfabeta. Bandung.

Bappeda Provinsi NTB. 2009. Rencana Pembangunan Jangka Menengah Daerah (RPJMD) Propinsi Nusa Tenggara Barat Tahun 2009-2003. Mataram.

2012a. NTB Bersaing, Ikhtiar dan Fakta 2009-2011. Mataram.

2012b. Fakta dan Aksi Percepatan Penanggulangan Kemiskinan di NTB 2009-2011. Mataram.
Badan Pusat Statistik NTB. 2009.Indeks Pembangunan Manusia (IPM) Provinsi Nusa Tenggara Barat Tahun 2009. Kerjasama Bappeda NTB dengan BPS, NTB, Mataram. 2012. NTB dalam Angka Tahun 2009-2011. Mataram 2013.Statistik Daerah Provinsi Nusa Tenggara Barat. Mataram.

Cascio, Wayne, F. 2003. Managing Human Resources. Productivity, Quality of Work Life, 6th.ed. McGraw-Hill International Edition.

Chaudry, M. S. 2012. Fundamental Of Islamic System diterjemahkan Suherman Rosyidi: Sistem Ekonomi Islam Prinsip Dasar. Kencana Prenada Group. Jakarta.

Danim, S. 2004. Ekonomi SDM, Analisis Ekonomi Pendidikan, Isu-Isu Ketenaga kerjaan, Pembiayaan Investasi, EkuitasPendidikan, Industri Pengetahuan. Pustaka Setia. Bandung.

Diana, N. U. 2008.Hadis-Hadis Ekonomi.UINMalang Press. Malang.

Djuwariah. 2008.Peningkatan Kualitas SDM Melalui Pendidikan Islam. Jurnal eLTarbawi 1(1): 13-26.

Elfindri dan W. Saputra. 2005.Kemiskinan dan Strategi Penyesuaian: Studi Empiris Sumatra Barat Dengan Data Susenas 1999 dan 2003. Jurnal Ekonomi Indonesia 1(2): 17-29.

Fauzi, Y. 2012.Memaknai Kerja.Mizan. Bandung.

Hamid, E. S. 2002.Indeks Pembangunan Manusia Dan Pengeluaran Konsumsi Masyarakat. Kasus: Yogjakarta.Jurnal Ekonomi Pembangunan, Kajian Negara Berkembang 7(2): 171-180.

Ibrahim, S. 2007. Kemiskinan Dalam Perspektif Al-Qur'an. UIN-Press. Malang.

Jusmaliani. 2011. Pengelolaan Sumber Daya Insani. Bumi Aksara. Jakarta.

Jauhar, A. A. H. 2009. Maqashid Syariah. Amzah. Jakarta.

Kaelany, H. D. 2005. Islam dan Aspek-Aspek Kemasyarakatan. Edisi-2. Bumi Aksara. Jakarta. 
Kamil, S. 2011. Wakaf Untuk Keadilan Sosial: Antara Teori dan Praktek, Al-Waqaf. Jurnal Wakaf dan Ekonomi Islam 4(1): 60 87.

Majid, A. M. S. 2011. Mengentaskan Kemiskinan Dalam Perspektif Ekonomi Syari'ah, Jurnal Ekonomi dan Keuangan Islam, 1 (2): 197 - 205.

Mubarok, S. 2012. Strategi Pendidikan Islam Dalam Meningkatkan Kualitas SDM. Jurnal El-Hikmah 10(1): 102-128.

Mulyadi.2012.Ekonomi SDM, Dalam Perspektif Pembanguna.PT. RajaGrafindo Persada. Jakarta.

Notoatmodjo, S. 2009. PengembanganSDM. Rineka Cipta. Jakarta.

Nugroho, M dan E. Suprianto. 2010. Model Peningkatan Efektivitas Kinerja Program Nasional Pemberdayaan Masyarakat Mandiri (PNPM) Mandiri Perkotaan Untuk Mengentaskan Kemiskinan, Jurnal Riset Bisnis Indonesia 6(1:38 -58 .

Pusat Pengkajian dan Pengembangan Ekonomi Islam (P3EI) Universitas Islam Indonesia, atas Kerjasama Dengan Bank Indonesia. 2008.Ekonomi Islam.PT. Radja Grafindo Perkasa. Jakarta.

Qardhawi, Y. 2005. Spektrum Zakat Dalam Membangun Ekonomi Kerakyatan. Zikrul Hakim. Jakarta.

Saebani, B. A dan A. Hamid. 2010. Ilmu Akhlak. Pustaka Setia, Bandung.

Santoso, R. P. 2012.Ekonomi SDM dan Ketenagakerjaan.UPP STIM YKPN. Yogyakarta.
Setiawan, M. B. dan A.Hakim.2013.Indeks Pembangunan Manusia. Jurnal Ekonomia 9(1):18-26.

Stamboel, K. A. 2012.Panggilan Keberpihakan, Strategi Mengakhiri Kemiskinan Di Indonesia.PT. Gramedia Pustaka Utama. Jakarta.

Utami., P.R.B. 2009. Menekan Angka Kemiskinan Melalui Peningkatan Pendidikan Bagi Wanita; Studi Kasus Kota Surabaya,Jurnal Riset Economi1(3): 263277.

Wattie, A. M. 2007.Kondisi Ekonomi dan Budaya Lansia dalam SDM Tantangan Masa Depan. Pustaka Pelajar Bekerja Sama dengan PSKK UGM. Yogyakarta.

Winoto, J. dan H. Siregar. 2006.Peranan Pembangunan Infrastruktur Dalam Menggerakkan Sektor Riil.Jurnal Ekonomi Indonesia 1(1): 9-37.

Wiyono, V. H. 2003.Kualitas SDM Indonesia dan Globalisasi, Perspektif. Jurnal Ekonomi Pembangunan, Manajemen dan Akuntansi. 8(2): 163-175.

Yasa, M. I. G. W. 2002.Penduduk Usia Lanjut dan Masalah Sosial Ekonomi Pembangunan Daerah Bali, dalam Dinamika Kependudukan dan Pembangunan Di Indonesia Dari Perspektif Makro Ke Realitas Mikro. Lembaga Studi Filsafat Islam (LESFI). Yogyakarta.

Zadjuli, S. I. 2007. Reformasi Ilmu Penge tahuan dan Pembangunan Masyarakat Madani di Indonesia. Journal of Islamic Busines and Economics 1(1): 29-52.

Zainuddin. 2006. Filsafat Ilmu Perspektif Pemikiran Islam. Lintas Pustaka. Jakarta. 